\title{
Nutritional Quality and Effect on Disease Prevention of Vegetables
}

\author{
João Silva Dias \\ University of Lisbon, Instituto Superior de Agronomia, Tapada da Ajuda, Lisboa, Portugal \\ Email: mirjsd@gmail.com
}

How to cite this paper: Dias, J.S. (2019) Nutritional Quality and Effect on Disease Prevention of Vegetables. Food and Nutrition Sciences, 10, 369-402.

https://doi.org/10.4236/fns.2019.104029

Received: March 11, 2019

Accepted: April 16, 2019

Published: April 19, 2019

Copyright (C 2019 by author(s) and Scientific Research Publishing Inc. This work is licensed under the Creative Commons Attribution International License (CC BY 4.0).

http://creativecommons.org/licenses/by/4.0/

\begin{abstract}
Vegetables have remarkable nutritional and health benefits. There are good reasons to include vegetables in human diet since they are enriched in bioactive compounds and by this reason they may help reduce the risk of some diseases. In this paper it was analyzed the nutrition quality and effect on disease prevention of vegetables. Each vegetable family and each vegetable contain a unique combination of bioactive compounds. The health benefit of vegetables should not be linked to one type of vegetable. It is presented some experimental research evidences that vegetables exert anti-oxidative, anti-carcinogenic, anti-diabetic and cardiovascular disease lowering effects. The mechanism by which vegetable bioactive compounds decrease the risk of some of these diseases is complex and sometimes unknown.
\end{abstract}

\section{Keywords}

Vegetables, Health Benefits, Healthier Life, Nutrition, ANDI, Bioactive

Compounds, Antioxidants, Dietary Fiber, Vitamins, Minerals,

Phytochemicals

\section{Introduction}

Vegetables are important for nutritional balanced diets since they supply bioactive compounds such as dietary fiber, vitamins, minerals, and phytochemicals [1] [2] [3]. They are also associated with disease prevention by improvement of gastrointestinal health, good vision, and reduced risk of chronic and degenerative diseases such as cardiovascular diseases, certain cancers, diabetes, rheumatoid arthritis and obesity [3]-[8].

In recent years consumers began to be more aware of the relation of eating patterns with nutrition and human disease prevention and there is a general agreement among scientists, nutritionists and dieticians that the promotion of a 
greater consumption of vegetables will improve nutrition quality and will bring health benefits.

The mechanisms by which vegetable consumption prevents diseases have not yet been fully understood [2] [3]. However, scientists, nutritionists and dieticians believe that the bioactive compounds such as dietary fiber, vitamins, minerals, and phytochemicals contents are responsible for mitigating some human diseases. All these different compounds may contribute to the overall health benefit. So the health benefit of vegetables should not be linked to only one bioactive compound or one type of vegetable, but rather with a balanced diet that includes more than one type of vegetable [1] [2] [3].

Some vegetable phytochemicals (glucosinolates, thiosulfates, polyphenols, bioactive peptides, etc.) have positive effects on health. They are strong antioxidants and they reduce the risk of chronic diseases by protecting against free radical damage, by modifying metabolic activation and detoxification of carcinogens, or even by influencing mechanisms that alter the course of tumor cells [1] [2] [3]. Phytochemicals are the key to better health as well as disease prevention.

All vegetables are sources of important vitamins (C, A, B1, B6, B9, E) and minerals, and consequently have nutritional and health benefits [2] [3].

Dietary fiber is a major constituent of vegetables. Dietary fiber and other bioactive molecules content have been usually addressed separately in nutritional studies. However, vegetables dietary fiber transports, through the human gut, a significant amount of phytochemicals, vitamins, and minerals linked to the fiber matrix [9] [10]. Therefore, associated phytochemicals, vitamins and minerals of the whole food may contribute to the overall health benefit usually attributed to the dietary fiber of vegetables [2] [3].

The objective of this paper is to explore the nutritional quality and effect on disease prevention of vegetables.

\section{Nutritional Quality of Vegetables}

\subsection{Vegetables}

From more than 1000 plants that are used as vegetables, Kays and Dias [11] [12], based in a world survey, report that at least 402 vegetables are cultivated and commercialized worldwide. They represent 69 families and 230 genera. From these great diversity leafy and stalk vegetables group comprised 53\% of the total, followed by fruit and flower vegetables group (15\%), and below ground (root, bulb, and tuber) vegetables group (17\%). Many of these vegetable crops have more than one part used.

Leafy and stalk vegetables group include: lettuce, chicory, coles (head cabbages, kales, tronchudas, collards, Brussels sprouts, etc.), Chinese cabbage, pak-choi, turnipgreens, mustards, rocket, watercress, Swiss chard, spinach, purslane, New Zealand spinach, celery, asparagus, rhubarb, fennel, chives, parsley, coriander, etc.

Fruit and flower vegetables group include: tomato, pepper, eggplant, water- 
melon, melon, cucumber, squash, pumpkin, zucchini, bitter gourd, peas, beans, lentils, okra, sweet maize, cauliflower, broccoli, kailan, broccoletti, artichoke, etc.

Root, bulb, and tuber vegetables group include: carrot, garden beet, turnip, radish, rutabaga, parsnip, sweet-potato, cassava, celeriac, onion, garlic, shallot, leek, Welsh onion, potato, etc.

\subsection{Vegetables and Human Nutrition}

Until few years ago it was believed, that the key for human nutrition and health, it was only 14 vitamins and 16 essential minerals. Recently, with the great developments in chemistry, it was found that, in addition to these vitamins and minerals, vegetables contain thousands of beneficial phytochemicals. As mentioned some vegetable's phytochemicals are robust antioxidants and are believed to reduce the risk of some chronic and degenerative diseases [2] [3] [4].

With the exclusion of the organosulfur compounds (OSCs) glucosinolates and thiosulfates (which are distinct phytochemicals of Brassicaceae and Alliaceae families, respectively), the phytochemicals, vitamins, and minerals content of many vegetables lie principally in dietary fiber, polyphenols (carotenoids, flavonoids), vitamin C, folate, calcium and selenium [2] [3]. The principal dissimilarity is that each vegetable family incorporates a distinct amalgam and amount of these bioactive compounds, which differentiate them from other vegetables [2] [13].

Vegetables of the Apiaceae family (carrot, parsnip, celery, celeriac, fennel, parsley, coriander, etc.) are rich in flavonoids, carotenoids, vitamin C, and vitamin E. For example celery and parsley are among the best vegetables sources for the flavonoid apigenin and vitamin E [2] [14], and carrots have a unique combination of three flavonoids: kaempferol, quercetin, and luteolin [15] [16] [17].

Vegetables of the Asteraceae or Compositae family (lettuce, endive and escarole chicories, stem lettuce, globe artichoke, etc.) are rich in flavonoids, tocopherols and conjugated quercetin. Crozier et al. [18] observed sizeable variations in flavonol content within lettuce cultivars. The outer leaves of "Lollo Rosso", a red cultivar, contained $911 \mu \mathrm{g} / \mathrm{g}$ fresh weight of quercetin, in contrast with the common head lettuce that contained only $11 \mu \mathrm{g} / \mathrm{g}$. And the levels in iceberg lettuce were even lower than in the head lettuce. The red color of "Lollo Rosso" lettuce is due to high levels of anthocyanins, which like quercetin, are products of the phenylpropanoid pathway. As one end-product of the pathway has been elevated, it may well be that other related compounds, including the flavonols, are also found in higher concentrations. Roman lettuce is richer in lutein than head lettuces; and leafy and roman lettuces are richer in quercetin [3] [13].

The Chenopodiaceae family vegetables (Swiss chard, spinach, garden beet, quinoa, etc.) are among those that are rich in oxalates [19] [20], but also excellent sources of dietary fiber, vitamins, calcium, manganese, flavonoids and carotenoids. When oxalates become too concentrated in body fluids, they can crystallize and cause health problems such as kidney calcium oxalate stones. 
The Cucurbitaceae family vegetables (e.g. squash, pumpkin, cucumber, melon, bitter gourd, etc.) are rich in carotenoids, and tocopherols, and vitamin C [21]. Burger et al. [22] in a survey of 350 melon accessions observed a 50-fold variation in ascorbic acid content, ranging from $0.7 \mathrm{mg}$ to $35.3 \mathrm{mg} / 100 \mathrm{~g}$ fresh weight. Ascorbic acid and $\beta$-carotene content ranged from 7.0 to $32.0 \mathrm{mg} / 100 \mathrm{~g}$ and 4.7 to $62.2 \mu \mathrm{g} / 100 \mathrm{~g}$, respectively in sweet melons [23].

The vegetables of the Leguminosae or Fabaceae family (all the legumes, e.g. pea, bean, soy-bean, lentils, chickpea, etc.), mature and immature seeds, are great sources of dietary fiber, resistant starch, protein, isoflavonoids [24], calcium and iron. Mallillin et al. [25] studied the total, soluble and insoluble fiber and fermentability characteristics of ten legumes mature seeds (mungbean, soyabean, peanut, pole sitao, cowpea, chickpea, green pea, lima bean, kidney bean and pigeon pea). They concluded that the dietary fiber content in these 10 legumes ranged from 20.9 to $46.9 \mathrm{~g} / 100 \mathrm{~g}$ and that the best sources after in vitro fermentation using human faecal inoculum stimulating conditions in the human collon (as $\mathrm{mmol} / \mathrm{g} /$ fibre isolate of acetate, propinate, and butyrate produced after fibre fermentation), were pole sitao and mungbean (acetate), kidney bean and pigeon pea (propinate), and peanut and cowpea (butyrate). High-flavonol legumes include sugar snap peas and mange-tout, which were found to contain 98 and $145 \mu \mathrm{g}$ quercetin/g respectively [2]. As mentioned some legumes are also rich in iron. Trinidad et al. [26] studied the mineral availability in vitro of iron, zinc and calcium in ten local legumes (cowpeas, mung beans, pole sitao, chickpeas, green peas, groundnuts, pigeon peas, kidney beans, lima beans and soyabeans). They found that the highest iron availability among these legumes was for lima beans and mung bean; while for zinc and calcium, the highest availability was for kidney beans and pigeon peas. Groundnuts have the lowest iron, zinc and calcium availability. They concluded that mineral availability of iron, zinc, and calcium from legumes differs and may be attributed to their mineral content, mineral-mineral interaction and from their phytic and tannic acid content. Mung bean either eaten as whole pod grains or grown to produce bean sprouts, is an important source of iron for women and children throughout South Asia [1] [27].

Vegetables of the Brassicaceae or Cruciferae family, which include kales, collards, cabbages, Brussels sprouts, cauliflower, broccoli, kailan, pak-choi, Chinese cabbage, turnip, broccoletti, swede, watercress, radish, horseradish, rocket, mustards, etc. are high sources of glucosinolates, as well as vitamin C, carotenoids, folates, calcium, and can accumulate selenium. Comparative studies of glucosinolate profiles within each Cruciferae, and among accessions and plant parts, indicate significant quantitative and qualitative differences [28]-[39]. Kushad et al. [34] observed in sixty-five brocolli cultivars, that glucoraphanin was the predominant glucosinolate and that there was more than 27-fold difference between the highest concentration in "Brigadier" and the lowest in "EV6-1". Hansen et al. [40] also observed in twenty-one red cabbage and six white cabbage cultivars, a considerable variation in the concentration of glucosinolates. Red cabbages were 
found to contain significantly higher concentrations of glucoraphanin compared to white ones. There were also significant differences within the red cabbages examined: "Rodima" had the highest level of glucoraphanin $(7.4 \mathrm{mg} / \mathrm{g})$ whereas "Primero" has the lowest $(0.6 \mathrm{mg} / \mathrm{g})$. The white cabbages presented significantly higher levels of glucoiberin compared to red ones: white cabbage "Bartolo" had the highest concentration of glucoiberin $(7.4 \mathrm{mg} / \mathrm{g})$, whereas "Candela" has the lowest $(1.7 \mathrm{mg} / \mathrm{g})$ and red cabbages ranged from 3 to $0.3 \mathrm{mg} / \mathrm{g}$. The red cabbages were also found to contain significantly higher levels of gluconasturtiin compared to white: "Amager Garo" had the highest level of gluconasturtin $(1 \mathrm{mg} / \mathrm{g})$ whereas "Primero" had the lowest $(0.1 \mathrm{mg} / \mathrm{g})$. In turnip and rutabagas were also observed similar differences between accessions [30]. Fahey et al. [41] evaluated glucosinolate content of broccoli sprouts and found that they contain nearly 20to 50 -fold higher glucosinolates concentrations than tissue from mature plants. In broccoli heads, the predominant glucosinolates are glucoraphanin, glucobrassicin, progoitrin, and gluconasturtiin [32] [34] [36] [38] [42] [43]. In cabbage, Brussel sprouts, cauliflower, kale, tronchuda and collard the most significant glucosinolates are sinigrin, progoitrin, and glucobrassicin [29] [32] [34] [39] [40] [44]. In turnip and rutabagas, the major glucosinolates are glucoerucin, glucoraphanin, and glucobrassicin [30] [33]. In radish, the most significant glucosinolates are glucoerucin, glucoraphanin, and glucobrassicin [31] [35]. Each of these Cruciferae also contain smaller amounts of other glucosinolates.

Cao el al. [45] observed that in Brassicaceae vegetables vitamin C is the most abundant vitamin in coles (cabbage, broccoli, cauliflower, Brussels sprouts, tronchuda, and kale), and that kale rated as the second highest vitamins content, and the second highest among twenty-two vegetables. They are also excellent sources of folate. Brussels sprouts and broccoli rank among the highest vegetable sources for folate [46] [47]. Most of the Cruciferae are also good sources of calcium. Kales, tronchudas and collards contain the highest content in fiber and calcium when compared to other Brassicaceae. Vegetables of the Cruciferae family are able of accumulating selenium when grown on selenium enriched soils. Banuelos and Meek [48] stated that broccoli grown soils with high-selenium levels accumulated 7-fold more selenium than cabbage, collards and Swiss chard.

Vegetables of the Alliaceae family (e.g. onions, garlic, shallots, leek, Welsh onion, chives, etc.) are rich in thiosulfates, flavonoids, calcium, potassium, manganese, chromium and can accumulate selenium. The types and composition of thiosulfates differs from Alliums [49]. Kalra et al. [50] reported that garlic fresh bulbs contain thirty-three thiosulfates. The major thiosulfates in the cytoplasm of Allium species are S-allyl-cysteine sulfoxide (alliin), S-methyl-cystein sulfoxide (methiin), and $\gamma$-glutamylcysteine [51]. Other minor thiosulfates include S-propenyl-cystein sulfoxide (isoalliin) and S-ethyl-cystein (ethiin) [52]. None of the thiosulfates found in Alliums have been detected in other vegetables, except S-methyl-cystein sulfoxide (methiin) which was detected in some Cruciferae [53]. The most important thiosulfates detected in onion bulbs are isoalliin (49\%), methiin (34\%), propiin (6\%), ethiin (5\%) and alliin (5\%); and in 
garlic alliin (92\%), methiin (8\%) and trace amounts of ethiin, propiin, and isoalliin [51] [53] [54] [55].

The second most important group of bioactive compounds in Alliums are flavonoids. Miean and Mohamed [56] mentioned that onion leaves had the highest total flavonoid content among sixty-two different vegetables. About 55\% of this total of flavonoids is quercetin, $31 \%$ kaempferol, and $14 \%$ luteolin. Two flavonoids are found in onion bulbs: anthocyanins in red onions, and flavonols like quercetin (more than 95\%) and kaempferol in most yellow onion varieties [57]. White onion cultivars have significantly less quercetin than the red ones [2] [3] [58]. In garlic cloves, $72 \%$ of the total flavonoids is myricetin, $23 \%$ apigenin, and 5\% quercetin [56]. In chive, garlic chive, and leek the predominant flavonoid is kaempferol [58].

Onion and garlic are excellent sources of calcium, potassium and manganese providing up to $10 \%$ of the human daily requirements. Most of the onions and garlics contain very low concentrations of selenium but can accumulate selenium when grown on selenium enriched soils. Ip and Lisk [59] reported that garlic fertilized with a high selenium and low sulfur fertilizer accumulated between 110 and $150 \mathrm{ppm}$ selenium, while onion accumulated up to $28 \mathrm{ppm}$. Onions also contain chromium [2]. Two hundred grams of onions contain up to $20 \%$ of the daily requirements in chromium. Onions are a rich source of dietary fibers and especially of inulin, a polyfructosan that has prebiotic properties [2] [3].

Vegetables of the Solanaceae family that includes tomato, potato, sweet and hot peppers, eggplant, etc. are very diverse, in their contribution to bioactive compounds.

Tomato is the second most produced and consumed vegetable in the world after potato. Tomato has a unique nutritional and phytochemical profile. Carotenoids are the major bioactive compounds in tomato with $60 \%$ to $64 \%$ lycopene, $10 \%$ to $12 \%$ phytoene, $7 \%$ to $9 \%$ neurosporene, and 10 to $15 \%$ carotenes [60]. Red varieties of tomato contain more lycopene (on average $90 \mathrm{mg} / \mathrm{kg}$ ) than yellow ones $(5 \mathrm{mg} / \mathrm{kg})$ [61]. The average daily intake of lycopene in human diet is about $25 \mathrm{mg} /$ day. Processed tomatoes (juice, sauce, paste, and ketchup) contain higher lycopene (2- to 40-fold) than fresh tomatoes [60] [62] [63]. Lycopene is a very potent antioxidant [64] [65].

Tomato contains also significant amounts of $\alpha-, \beta-, \gamma-\delta$-carotene (0.6 to 2.0 $\mathrm{mg} / \mathrm{kg}$ ) which make it for consumers a top contributor of provitamin A and vitamin A [66] [67]. Tomatoes are also an excellent source of vitamin C [68]. Tomato contains small amounts of lutein, $\alpha$-, $\beta$-, and $\gamma$-tocopherols, and conjugated flavonoids (quercetin and kaempferol) [66] [69] [70] [71]. About $98 \%$ of these flavonoids are present in the peel [72]. Cherry tomatoes cultivars have higher flavonoids content than beef ones, and field-grown tomatoes have higher flavonoids content than greenhouse-grown ones [18] [72]. Tomatoes are also an excellent source of potassium. 
Potato is usually only associated as a source of carbohydrates. But it is also an excellent source of essential amino acids (such as lysine) and other bioactive compounds [2]. In addition to superior quality proteins, potato tubers also have significant amounts of vitamins and minerals, as well as phytochemicals (phenolics, phytoalexins, etc.), and protease inhibitors [73] [74]. There are yellow, red, and purple fleshed potato cultivars with high content of phytochemicals, nevertheless some cultivars are known to have lower [2]. Other bioactive antioxidants presented in potato tubers include $\alpha$-tocopherol, lutein, $\beta$-carotene, folates and selenium [73] [74].

Peppers are excellent sources of vitamins $\mathrm{C}, \mathrm{K}$, carotenoids, and flavonoids [75]. They provide also a respectable amount of dietary fiber. Peppers contain in average 1 to $2 \mathrm{~g} / \mathrm{kg}$ vitamin C, which is equivalent to 200 to $300 \%$ of the recommended daily allowance [76]. Their content of provitamin A carotenoids ( $\alpha$ - and $\beta$-carotene) depends in the cultivar. Some cultivars of hot pepper have $12 \mathrm{mg} / \mathrm{kg}$ total carotenoids, while others have trace amounts [76] [77]. In pepper major conjugated flavonoids are quercetin and luteolin. Their content varies among cultivars ranging from not detectable to $800 \mathrm{mg} / \mathrm{kg}$ [78]. Red bell peppers have significantly higher levels of bioactive compounds than green ones. Red bell peppers also contain lycopene [74].

In hot peppers or chilies the major phytochemicals are capsaicinoids [2] [74]. More than 20 capsaicinoids, belonging to capsaicin and dihydrocapsaicin groups, have been identified. Capsaicin contributes about $70 \%$ for the pungent/hot fire flavour in chili peppers, while dihydrocapsaicin represents $30 \%$ [79]. Significant variations in capsaicinoids are found between and within peppers, ranging from about $220 \mathrm{ppm}$ in Capsicum annum (sweet pepper) to 20,000 ppm in Capsicum chinense (hot pepper) [80]. Fresh chili peppers have high levels of vitamins and minerals. Just $100 \mathrm{~g}$ of hot peppers, red or green, provides $240 \%$ of vitamin C, $39 \%$ of vitamin B6-complex group, $32 \%$ of vitamin A, $13 \%$ of iron, $14 \%$ of copper, $7 \%$ of potassium, of the recommended daily allowance [81]. Chilli peppers contain a good amount of manganese and magnesium [2].

Eggplant besides vitamins ( $, \mathrm{K}, \mathrm{B} 6$-complex group, folate, and niacin) and minerals (magnesium, copper, manganese, molybdenium, potassium) also contains important phytochemicals like flavonoids, such as nasunin, and phenolic compounds, such caffeic and chlorogenic acid [2] [74]. Nasusin is the major phytochemical in purple eggplant cultivars. Nasunin is part of the anthocyanin purple pigment found in the skin of eggplant [82] [83] [84]. Matsuzoe et al. [85] examined the profile of anthocyanins in several eggplants and found that nasunin represents between $70 \%$ to $90 \%$ of the total anthocyanins in the skin. Nasunin is an antioxidant that effectively scavenges reactive oxygen species, such as hydrogen peroxide, hydroxyl and superoxide, as well as inhibits the formation of hydroxyl radicals, probably by chelating ferrous ions in the Fenton reaction [82] [84]. The predominant phenolic compound found in all cultivars of eggplant tested by Matsuzoe et al. [85] is chlorogenic acid, which is one of the most potent free radical scavengers found in plant tissues. Benefits attributed to 
chlorogenic acid include anti-mutagenic (anti-cancer), anti-microbial, anti-low density lipoproteins, and anti-viral activities. In addition to chlorogenic acid, Whitaker and Stommel [86] found 13 other phenolic acids present in seven eggplant cultivars. "Black Magic" was found by these authors to have nearly three times the amount of antioxidant phenolics as the other eggplant cultivars studied. Eggplant fruits also contain several other antioxidants including flavonoids myricetin and kaempferol as well as carotenoids lycopene, lutein, and $\alpha$-carotene [56] [87]. Eggplant is richer in nicotine than any other edible vegetable and contains measurable amounts of oxalates [2] [74]. Due to oxalates individuals with already existing and untreated kidney or gallbladder problems may avoid eating eggplant [74] [88].

Looking generally for the nutrition quality of vegetables groups we can say. In the leafy and stalk vegetables they are fiber sources, rich in important minerals such as calcium, magnesium and iron, and vitamins $\mathrm{C}$, $\mathrm{A}$ and riboflavin. In this group young fresh leaves contain more vitamin $C$ than mature plants. The thinner and greener leaves are more nutritious respecting vitamins and minerals but less nutritious respecting dietary fiber. The green outer leaves of head or pseudo-head leafy vegetables such as cabbage, lettuce, and endive chicory, are usually richer in calcium, magnesium, iron, and vitamins than the inner leaves. Stalk vegetables like tronchuda cabbage, pak-choy, celery and asparagus are rich in dietary fiber.

In the fruit and below ground organ vegetables the skin and inside color reflect different bioactive compounds/pigment present. Anthocyanins (flavonoid) give vegetable leaves, below ground organs and fruits their purple and purple-red colour appearance, such as in red anthocyanin lettuce and endive chicory, red cabbage, Swiss chard, rhubarb, etc. (leafy and stalk vegetables), garden beet, purple carrot, red onion, purple and purple-red skinned potato, purple sweet potato, etc. (below ground vegetables) and purple eggplant, purple tomato, purple pepper, purple and black broccoli, purple corn, etc. (fruit and flowering vegetables). The most abundant carotenoids in vegetables are $\alpha$-carotene, $\beta$-carotene and lycopene (carotenes), and lutein, zeaxanthin, and $\beta$-cryptoxanthin (xanthophylls) [2] [74] [89]. The most common carotenes are $\beta$-carotene and lycopene. $\beta$-carotene (as well as $\alpha$-carotene) can be found in orange and yellow skin fruits, below ground organs and leafy vegetables [2] [74]. As a rule of thumb, the greater the intensity of the orange colour the more $\beta$-carotene the vegetable contains [2] [74]. Lycopene can be found in red fruits (e.g. tomato), red below ground organs (e.g. red carrot) and red leafy vegetables. Lutein is the most abundant xanthophyll [2] [74]. Xanthophylls are responsible for the yellow colour of vegetables.

\subsection{ANDI and Nutritional Quality of Vegetables}

ANDI (Aggregate Nutrient Density Index) is a scoring system based on nutrient content, rated on a $1-1000$ scale that was established by Dr. Fuhrman [90]. This index are scores attributed to a variety of vegetables (and other foods) based on 
how many nutrients they deliver to our body in each calorie consumed. It was calculated by evaluating the content of dietary fiber, vitamins, minerals, phytochemicals, antioxidant capacities, etc. It is an index that estimates the nutritional quality of vegetables. Table 1 presents the highest ANDI scores in leafy vegetables.

Three main vegetables families are shown in this table: Brassicaceae (kale, collard greens, mustard greens, turnip greens, watercress, pak-choy, Chinese cabbage, Brussels sprouts, rocket, cabbage and broccoletti); Chenopodiaceae, (Swiss chard and spinach); and Asteraceae (green leaf lettuce, chicory and Romaine lettuce). The highest ANDI scores of non-leafy vegetables are presented in Table 2 .

Table 2 also shows other Brassicaceae like radish, turnip, kohlrabi, cauliflower, and rutabaga. Different vegetables from various families are also shown as well as differences among the peppers, where orange pepper is better than the red and red better than the green pepper.

Leafy vegetables thus have the highest ANDI scores compared to other vegetables. They are rich in dietary fiber, carotenoids, vitamin C, vitamin E, flavonoids, calcium, magnesium, etc. All the leafy vegetables are good sources of magnesium because they have chlorophyll.

The leafy vegetables with high ANDI scores are Brassicaceae. They have dietary fiber and are a rich source of glucosinolates and other bioactive nutrients, and have a very high content in calcium and $\beta$-carotene. They are excellent sources of lutein and can also accumulate selenium.

Another important family is Chenopodiaceae. A recent research has shown that Swiss chard leaves contain at least thirteen distinct polyphenol antioxidants [91] comprising the flavonoids kaempferol and syringic acid [91] [92] [93]. Swiss chard and garden beet leaves have are a unique source of the bioactive antioxidants named betalains [2] [74]. Nine betacyanin pigments were identified in the reddish-purple stems and veins of the leaves of Swiss chard and beet [94]. In the Swiss chard's yellowish stems and veins were identified nineteen betaxanthin pigments, including histamine-betaxanthin, alanine-betaxanthin, tyramine-betaxanthin, and 3-methoxytyramine-betaxanthin [94].

In Asteracea, lettuces and chicories are the main vegetables used in raw salads. Leaf and Romain lettuces have higher ANDI scores (585 and 510 respectively) than iceberg lettuce. Besides the nutritive value of leaf and Romaine lettuce are higher than head lettuces (butter and batavia types). They have more dietary fiber, minerals, vitamins, and phytochemicals. Raw vegetables are the healthiest food we can eat since some phytochemicals are only available if we eat the vegetables raw [95].

In the non-leafy vegetables we have after radish and turnip (both Brassicaceae) the carrots. They are high in fiber and nutrient rich. Carrots have different colors. Orange carrots have $\alpha$ - and $\beta$-carotene (vitamin A-rich carotenoids) and purple carrots are rich in anthocyanins (flavonoids) and low in carotenoids [96] [97]. Winter squash "Acorn" has a high $\beta$-carotene content. Kohlrabi, cauliflower 
Table 1. List of identified leafy vegetables with the highest ANDI scores.

\begin{tabular}{lclc}
\hline \multicolumn{1}{c}{ Vegetable } & ANDI & \multicolumn{1}{c}{ Vegetable } & ANDI \\
\hline 1) Kale & 1000 & 9) Chinese cabbage & 714 \\
2) Collard greens & 1000 & 10) Brussels sprouts & 672 \\
3) Mustard greens & 1000 & 11) Rocket & 604 \\
4) Swiss chard & 1000 & 12) Lettuce, green leaf & 585 \\
5) Turnip greens & 1000 & 13) Chicory & 516 \\
6) Watercress & 1000 & 14) Romaine lettuce & 510 \\
7) Pak-choi & 865 & 15) Cabbage & 481 \\
8) Spinach & 739 & 16) Broccoletti & 455
\end{tabular}

Table 2. List of identified non-leafy vegetables with the highest ANDI scores.

\begin{tabular}{lclc}
\hline \multicolumn{1}{c}{ Vegetable } & ANDI & \multicolumn{1}{c}{ Vegetable } & ANDI \\
\hline 1) Radish & 502 & 7) Cauliflower & 315 \\
2) Turnip & 473 & 8) Rutabaga & 296 \\
3) Carrots & 458 & 9) Bell pepper, Red & 265 \\
4) Winter squash “Acorn” & 444 & 10) Bell pepper, Green & 258 \\
5) Bell pepper, Yellow/Orange & 371 & 11) Artichoke & 244 \\
6) Kohlrabi & 352 & 12) Asparagus & 234 \\
\hline
\end{tabular}

and rutabaga are also Brassicacea and so they are good sources of vitamins, minerals and healthy glucosinolates. Kohlrabi (stem) and rutabaga (roots) besides having high vitamin $\mathrm{C}$ and anti-oxidant content due to glucosinolates, are good alternative to potatoes since they are not starchy as potato and can be eaten raw and when sliced they do not produce discoloration. The nutritional value of the outer leaves of cauliflower is much higher than the flower buds. Artichoke is rich in fiber and a good source of minerals, namely calcium, potassium and phosphorus. It contains also many bioactive compounds such as glycosides and phenolics, mainly caffeicinic acid [98]. Asparagus besides rich in fiber is a very rich source of folic acid.

\section{Effect on Disease Prevention of Vegetables}

\subsection{Effect on Cancers}

The International Agency for Research on Cancer (IARC) estimates that the percentage of cancers due to unbalanced diets with low vegetable intake and low consumption of complex carbohydrates and dietary fiber, ranges from 5\% to $12 \%$ for all cancers, and $20 \%$ to $30 \%$ for upper gastrointestinal tract cancers [2] [3]. The World Health Organization (WHO) states that about $14 \%$ of worldwide deaths are attributable to gastrointestinal cancers due to inadequate vegetable and fruit consumption [99]. The American Cancer Society observed that more than two-thirds of cancers deaths in the United States are avoidable, and report 
that one-third of cancer deaths can be prevented by a proper diet rich in vegetables [100] [101].

Numerous epidemiological studies conducted in the United States and in developed countries, which include results from tests on adenomatous polyps (the precursors to colorectal cancer) concluded that high vegetable intake decrease the risk of colorectal cancer [26] [102] [103] [104] [105] [106]. Witte et al. [107] observed significantly lower incidence of colorectal polyps in men and women ages between 50 and 74 years old who consumed higher rates of vegetables namely crucifers, garlic and tofu. Interestingly is also that this research concluded that vegetables have more beneficial effects against colorectal polyps than fruits or fiber from grains. In another research with 41,837 women aged between 55 and 69 years old, Steinmetz et al. [106] found a $20 \%$ to $40 \%$ reduction in risk of colon cancer in populations with higher vegetable consumption. Other studies have also estimated lower risk of colon cancer, ranging from 3 to 8 fold due to high vegetable and fruit intake [26] [108] [109] [110]. Increasing the consumption of vegetables reduces the risk of cancer since the antioxidants in vegetables prevent the oxidative damage of the cells in the body [111] [112].

Leafy vegetables have protective effects against cancers, specially gastrointestinal carcinomas, mainly due to dietary fiber, but also to phytochemicals, vitamins (C, E, K, and A) and minerals they contain [113]. Tewani el al. [114] states that spinach shows protective effects against gastrointestinal cancer by reducing oxidative stress thanks to vitamins ( $\mathrm{C}$ and $\mathrm{E}$ ), carotenes (mainly $\beta$-carotene), lutein, and flavonoids (mainly flavones) it contains.

Cruciferous vegetables rich in glucosinolates have been shown to protect against lung, prostate cancer, breast cancer, and chemically induced cancers [115] [116] [117] [118] [119]. The evidence concerning the anti-carcinogenic effect of glucosinolates of Cruciferous was from in vivo studies, mainly with broccoli, using animal models and human volunteers [116] [118]-[124].

Intact glucosinolates have no biological activity against cancer. However their breakdown products have been shown to stimulate mixed-function oxidases involved in detoxification of carcinogens, reducing the risk of certain cancers [28] [125] [126]. Not all glucosinolate breakdown products have anticancer activity [127]. The glucosinolates glucoraphanin, glucoiberin, glucobrassicin and gluconasturtiin are involved in the anti-carcinogenic activity, and glucoraphanin is known to bolster the defenses of cells against carcinogens through an up-regulation of enzymes of carcinogen defense.

Epidemiological data show that a diet rich in Cruciferous can reduce the risk from several cancers by an intake of at least $10 \mathrm{~g}$ per day [115] [116] [118]. Epidemiological studies have suggested that diets rich in broccoli, may reduce the risk of prostate cancer, and consumption of one or more portions of broccoli per week can reduce the incidence and the progression from localized to aggressive forms of prostate cancer [118] [119]. There is also strong evidence that isothiocyanates (an important group of breakdown products of glucosinolates) from Cruciferous prevent bladder cancer, namely transitional cell carcinoma of the 
urinary bladder [128].

Consumption of Allium vegetables has been also found to retard growth of several types of cancers. A number of epidemiological studies show inverse correlations between the consumption of Allium vegetables, mainly onions and garlics, and the reduced incidence of cancers.

There is strong link between the consumption of onions and the reduced incidence of stomach and intestine cancers [129] [130]. Control studies reveal that consumption of 1 to 7 portions of onions per week reduces the risks of colon, ovary, larynx, and mouth cancers [131]. Mortality due to prostate cancer also appears to be reduced by a diet making a large consumption of onions [132]. Onion extracts prevent tumors by inhibiting the mutation process [133] and reducing the proliferation of cancer cells [134].

Epidemiological researches show the correlation between moderate garlic intake and a low esophageal and stomach tract cancers incidence [131] [135] [136]. Garlic extracts prevent tumor initiation by inhibiting the activation of pro-carcinogens and by stimulating their elimination [137] [138]. A regular consumption of garlic has been associated also with the reduction in the incidence of preneoplastic lesions occurring in the gastric mucosa of individuals infected by Helicobacter pylori [139]. Other studies analyzing the preventive effect of garlic have evidenced their suppressive potential on the development and progression of colorectal adenomas [110] [140]. A reduced cancer risk by regular consumption of garlic has been widely documented also for colorectal and prostate cancers [131] [136] [141] [142]. The impact of a diet rich in Allium vegetables in anti-prostate cancer is higher in men presenting localized rather than advanced forms [142].

The impact of a regular intake of Allium vegetables on the incidence of cancers affecting breast, endometrium and lungs have been studied in a limited number of investigations [143] [144] [145]. The risk of breast cancer was shown to decrease as consumption of Allium increased [143]. Onion extracts has apoptosis-inducing effects in epithelial MDA-MB-231 cells that cause breast cancer [146].

In tomato several investigations have shown an inverse relationship between plasma/serum lycopene concentrations and the risk of some cancers [147]-[153]. Reports on thirteen cancer types were identified in literature, of which breast, colorectal, gastric-gastrointestinal, and prostate cancers. For breast, colorectal, and gastric cancers, the existing data support a potential protective association between tomato and lycopene intake and cancer risk. People consuming diets rich in tomato/lycopene and tomato based products were found to be less likely to develop stomach and rectal cancers than those who consume lesser amounts [154]. Among the cancers investigated prostate cancer is the most widely researched. Tomato and lycopene intake is preventive against prostate cancer [13] [155]. Hadley et al. [156]. In an epidemiological study found that consuming tomato and tomato products was associated with a lower incidence of prostate cancer [156]. A prostate cancer risk reduction of nearly $35 \%$ was observed when 
the test subjects consumed ten or more servings of tomato per week [157]; and the effect was much stronger for patients with more aggressive and advanced stages of cancer [157].

Other Solanaceae associated with cancer prevention are chili peppers and eggplant. Chili peppers are tough to prevent cancer cells from growing, developing and spreading due to it capsaicin content [158]. A study of Nagase et al. [159] showed that eggplant extract inhibited human fibrosarcoma HT-180 cell invasiveness.

Consumption of legumes like soybean, chickpea, and lentil rich in isoflavonoids daidzen, genistein and gycitein, have been suggested to have multiple beneficial effects in a number of diseases, including certain types of cancer [160] [161]. Ziegler et al. [162] observed that Asian-American women who consumed a diet rich in soy had low risk of breast cancer incidence. Later studies of soy rich diets confirmed that the main anti-breast cancer ingredient is genistein [163] [164] [165]. Dong et al. [166] in a meta-analysis of prospective studies pointed out that soybean isoflavonoids intake is associated with a significantly reduced risk of breast cancer incidence in Asian populations, but not in Western populations. Epidemiological indications jointly with clinical data from animal and in vitro studies highly supported a positive correlation between soybean isoflavonoids consumption and protection towards prostate cancers [164] [167]. Besides breast and prostate cancer, soy isoflavonoids also exhibit inhibitory effects on ovarian cancer, leukemia and lung cancer [168].

Anti-carcinogenic effect of carrot juice extracts on myeloid and lymphoid leukemia cell lines was investigated by Zaini et al. [169]. Carrot juice extracts owned the ability to "kill" leukemia cells and inhibit their progression. Those researchers believed that $\beta$-carotene and falcarinol present in the carrot juice extract may have been responsible for this positive effect. As a complement of this study Larsen et al. [170] examined the impact of carrot and falcarinol feeding toward the development of azoxymethane-induced colon preneoplastic lesions in the rat colon. The results of this study demonstrated that diets with carrot and falcarinol have the potential to delay the development of large aberrant crypt foci and colon tumors on rats. Purup et al. [171] observed also that carrot extracts which contain falcarinol and related aliphatic C17-polyacetyenes (falcarindiol and falcarindiol 3-acetate), had significant inhibithory effect on intestinal cancer cell proliferation. Pisani et al. [172] in a case-control study show that smokers who eat carrots more than once a week have a smaller risk of lung cancer.

\subsection{Effect on Cardiovascular Diseases}

Vegetables offer protection against cardiovascular diseases since they are free of saturated fat, trans fat and cholesterol and rich in bioactive compounds such as dietary fibers, OSCs, flavonoids, carotenoids, phytoestrogens, monoterpenes and sterols. Unbalanced diets with low vegetable intake, has been estimated to cause about $31 \%$ of ischaemic heart disease and $11 \%$ of stroke worldwide [3]. An healthy diet with high vegetable consumption has been associated with lower 
risk of cardiovascular disease in humans [173] [174]. Liu et al. [175] test the influence of vegetable intake on the incidence of cardiovascular disease among 15,220 male physicians without a history of heart disease or stroke. The results of this investigation show that the participators who consumed more than two servings of vegetables per day had $25 \%$ less cardiovascular disease than those who consumed less than one serving. Based on this and other researches, the American Heart Association (AHA) has concluded that a diet high in vegetables and fruits may reduce the risk of cardiovascular disease in humans [176].

Prevention of cardiovascular diseases has been attributed to regular garlic consumption. Epidemiological studies demonstrate that there is an inverse correlation between garlic consumption and incidence of cardiovascular diseases [3] [74]. Yeh and Liu [177] show that garlic extracts and their OSCs have cholesterol and lipid lowering effects by inhibiting monooxygenase and HMG-CoA reductase two key enzymes involved in cholesterol and fatty acid syntesis. Moriguchi et al. [178] reported that garlic extracts have fibrinolytic effect by inhibiting lipid peroxidation and hemolysis of erythrocytes. Chang et al. [179] in their studies reported also the anti-platelet effect of sodium 2-propenyl thiosulfate from garlic, by inhibiting cyclooxygenase enzyme activity.

Similar to garlic, onions also contain a number of OSCs and flavonoids, such as quercetin, that can reduce the risks for cardiovascular diseases by increasing antioxidant capacity [3] [74] [180]. Hubbard et al. [181] in a pilot study in humans showed that the consumption of the equivalent of 3 onions in a soup was sufficient to significantly reduce the blood platelet aggregation. Platelet aggregation is an important risk for the development of coronary thrombosis and atherosclerosis. Briggs et al. [182] observed that by cutting raw onions S-alkenyl-L-cysteine sulfoxides are converted by enzyme alliinase into thiosulfinates and copaenes and these compounds inhibit platelet aggregation. Ried et al. [183] report also that onion and garlic had a blood pressure lowering effect by inhibiting angiotensin-converting enzyme activity and inducing intracellular nitric oxide and hydrogen sulfide production.

The consumption of leafy vegetables, due to bioactive compounds, increase antioxidant capacity and protect against oxidative stress which play an important role in the pathogenesis of cardiovascular diseases. Another reason is their low sodium, and high calcium and magnesium content [3] [74]. Furthermore that consumption also reduces blood pressure, inhibit platelet aggregation and improve endothelial dysfunction due to their rich inorganic nitrate content [184]. In diets where the consumption of leafy vegetables is high the rate of cardiovascular diseases is lower comparing with diets with less consumption [3] [74] [185]. Rastogi et al. [186] observed that individuals with consumption of more than three portions of leafy vegetables a day have an incidence of about $60 \%$ less of ischemic heart disease than those consuming less than one portion. Saluk et al. [187] report that anthocyanin extracted from red cabbage have protective effect on blood platelets. 
In broccoli, indole-3-carbinol and sulforaphane, which are hydrolysis breakdown products of glucosinolate glucoraphanin, are thought to be the major bioactive compounds protective against cardiovascular diseases [188] [189]. Jeffery and Araya [189] report that indole-3-carbinol and sulforaphane besides protecting against ischemic damage of the heart also protect against inflammation by inhibiting cytokine production [189]. Murashima et al. [190] reported in a study, with multiple biomarkers for metabolism and oxidative stress, that broccoli sprouts decrease levels of total cholesterol and low-density lipoprotein cholesterol and increase levels of high-density lipoprotein cholesterol.

Jorge et al. [191] show in their studies that eggplant is effective in the treatment of high blood cholesterol. Guimarães et al. [192] showed a significant decrease in blood levels of total cholesterol and low-density lipoprotein cholesterol in human volunteers who were fed with eggplant powder. Kwon et al. [193] presented eggplant phenolics as inhibitors of key enzymes relevant for type 2 diabetes and hypertension.

Legumes are also protective against cardiovascular diseases due to their high saponin and soluble fiber content [2] [3] [74]. Soluble fiber delays gastric emptying, slows glucose absorption and lowers serum cholesterol levels [194]. In several epidemiologic studies it was observed a positive correlation between increased legume consumption and reduced mortality due to cardiovascular disease [195] [196]. Consumption of legumes reduce the levels of total cholesterol and low-density lipoprotein cholesterol by inhibiting the absorption of bile acid from intestines and by promoting the formation of propionic acid and other short chain fatty acids that inhibit the synthesis of cholesterol [197].

Nicolle et al. [198] suggest that carrot intake may exert a protective effect against cardiovascular disease and that this protective effect may be due to the synergistic action of dietary fiber and antioxidant polyphenols in carrot. Gramenzi et al. [199] states that the consumption of carrots is associated with smaller risk of acute myocardial infarction in women. Gilani et al. [200] examined in rats the anti-hypertensive effect of DC-2 and DC-3, two cumarin glycosides from carrot. Their results showed that these glycoside compounds caused a decrease in arterial blood pressure in the rats. Further in vitro studies by the same researchers, demonstrate that the decreased blood pressure observed may be due to the calcium channel blocking action of cumarin glycosides DC-2 and DC-3 from carrots.

\subsection{Effect on Diabetes}

Dias and Imai [95] highlight the nutritional and health benefits of different vegetables and their dietary fiber, vitamin C, vitamin E, carotenoids, flavonoids, thiosulfates, magnesium, selenium, zinc, and chromium contents, to prevent and reverse diabetes. Besides they also analyzed when we should eat the vegetables, and mainly the effect of eating vegetables before carbohydrates on postprandial blood glucose levels, and glycemic control. Data of these authors shows that eating vegetables before carbohydrates is effective to reduce postprandial hypergly- 
cemia in type 2 diabetes patients, as well as in healthy people. So vegetables should be eaten before carbohydrates at every meal [95].

Carter et al. [201] in a systematic review and meta-analysis found that greater leafy vegetables consumption was colligated with $14 \%$ decrease in risk of type 2 diabetes. Another previous research reported that each daily serving of leafy-green vegetables generates a 9\% decrease in risk of type 2 diabetes [202]. Khan et al. [203] saw that oral feeding of regular rats for 60 days with a mustard (Brassica juncea) diet $(10 \% \mathrm{w} / \mathrm{w})$ led to significant hypoglycemic effect. This result was associated to the positive stimulation of glycogen synthetase and to the suppression of glycogen phosphorylase and some other gluconeogenic enzymes. As menthioned Swiss chard leaves contain syringic acid that have blood sugar regulating properties [91] [92] [93]. Syringic acid was demonstrated to inhibit the activity of $\alpha$-glucosidase enzyme. When $\alpha$-glucosidase gets inhibited, fewer carbohydrates are converted to sugars and blood sugar is able to remain more steady [204]. Garden beet leaves have the same properties, since beet and Swiss chard are both from the Chenopodiaceae family [3] [74]. Yoshikawa et al. [205], in a oral glucose tolerance test (OGTT) conducted in rats, that measures the body's ability to metabolize glucose [206], observed that several glycosides isolated from the root extract of beet increase glucose tolerance. Gu et al. [207] report that purslane had hypoglycemic effects in a study comparing the hypoglycemic and antioxidant activities of the fresh and dried purslane in insulin-resistant HepG2 cells and streptozotocin-induced diabetic mice. In another study in adult patients with type 2 diabetes it was found that consumption of purslane extract significantly reduced HbA1c levels and post-prandial blood glucose [208].

Alliaceae vegetables are necessary ingredients of a diabetes prevention diet. Garlic lowers blood sugar levels in diabetic patients [209] and administration of S-methyl cysteine sulfoxide isolated from onion restrained blood glucose and showed significant hypoglycemic effect in rats [2] [74]. El-Demerdash et al. [210] in a biochemical study on the hypoglycemic effects of onion and garlic in alloxan-induced diabetic rats report that these vegetables had a hypoglycemic effect. Other investigations evaluating the hypoglycemic, antioxidant and hepatoprotective potentials of onion show that onion consumption increased the levels of enzymes superoxide dismutase, catalase and glutathione peroxidase [211] and reduce insuline resistance [212]. Onions and other Alliaceae also contain chromium that is linked to diabetes prevention by enhancing insulin receptor kinases [213]. Clinical surveys on diabetic patients showed that chromium can decrease fasting glucose, ameliorate glucose tolerance and bring down insulin levels. Swamy et al. [209] observed that $200 \mathrm{~g}$ of some cultivars of onions contain chromium up to $20 \%$ of the daily requirements.

Nutritionists and dieticians commonly recommend diabetic eating carrots in moderation because they say that carrots contain more sugar than other vegetables. Although carrots are not a negative vegetable for the diabetic since they have fiber-rich fractions that transports a significant amount of polyphenols and carotenoids linked to the fiber matrix; they are relatively low in calories and the 
glycemic load is only 3 [97]. Carrots when are eaten raw their glycemic effect is lessened further as the body does not absorb all of the calories in raw aliments [3] [74]. Chau et al. [214] comparing the characteristics, functional properties, and in vitro hypoglycemic effects of various carrot insoluble fiber-rich fractions confirmed the great relationship between dietary fiber intake and lower risk of type 2 diabetes since those authors concluded, from their study, that the enhanced glucose absorbance capacity and reduction of amylase activity of dietary fiber of carrot help control pos-prandial serum glucose level. Recent research advocates that orange carrot with $\alpha$ - and $\beta$-carotene might help diabetics to succeed in their illness [97] [215]. Purple carrots, rich in anthocyanins and low in carotenoids, were also recently associated with reduction in impaired glucose tolerance [96].

Curcubitaceae is a very important family for diabetics since includes several vegetables with anti-diabetic properties. Bitter gourd (Momordica charantia) have been intensively studied for its anti-diabetic attributes. Different studies reported hypoglycemic and anti-hyperglycemic properties of bitter gourd [209] [216] [217] [218]. Clinical surveys on diabetic patients using pulp and juice extracts of bitter gourd were reported to bring down serum insulin levels, to lower fasting blood glucose levels, and to ameliorate glucose tolerance [219]. Vicine, charantin and polypeptide-p are the principal hypoglycemic bioactive compounds from bitter gourd [220]. But there are also carotenoids ( $\beta$-carotene, lutein, and zeaxanthin), triterpenoids (momordicin), alkaloids and saponins, responsible for their side effect on glycemic control [221]. Momordicin possess insulin-like activity [222].

Besides bitter gourd other non-sweet Curcubitaceae that have anti-diabetic properties are ivy gourd (Coccinia grandis), snake gourd (Trichosantes cucumerina), and ridge gourd (Luffa acutangula). In ivy gourd immature fruits have anti-hyperglycemic properties since they help regulate blood sugar levels [223]. In India they are used to prevent or treat diabetes [223]. Bioactive compounds in the ivy gourd inhibit glucose-6-phosphatase [211], a liver enzyme involved in the regulation of sugar metabolism. Snake gourd is also considered to be useful in treating type 2 diabetes [209]. Ridge gourd contains insulin like peptides, and alkaloids that help to lower fasting blood glucose levels [209] [217].

Legumes consumption is also colligated with reduced risk of type 2 diabetes since they are the ideal carbohydrate source [3] [90] [224]. They are low in glycemic load due to their moderate protein and abundant dietary fiber and resistant starch (that is fermented by bacteria in the colon). This chemical composition of legumes decreases the number of calories that can be absorbed which contribute to the control of blood sugar levels.

Kwon et al. [193] presented eggplant phenolics as inhibitors of key enzymes relevant for type 2 diabetes and hypertension.

\section{Conclusions}

Consumption of a vegetable rich diet has unquestionable positive effects on nu- 
trition and health since vegetables are rich in bioactive compounds such as dietary fiber, vitamins, minerals, and phytochemicals that can protect the human body from several types of chronic and degenerative diseases.

Leafy vegetables have the highest ANDI scores compared to other vegetables. The three leafy vegetables families with high ANDI scores are Brassicaceae Chenopodiaceae, and Asteraceae. Leafy and stalk vegetables are fiber sources, rich in important minerals such as calcium, magnesium and iron, and vitamins $\mathrm{C}, \mathrm{A}$ and riboflavin. Fruit and below ground organ vegetables, the skin and inside color reflect different bioactive compounds/pigment present.

In this article it was presented some experimental research evidences that the bioactive compounds are responsible for mitigating some human diseases. Anti-oxidative, anti-carcinogenic, anti-diabetic and cardiovascular disease lowering effects of bioactive compounds of vegetables have been reported. The mechanism by which vegetable bioactive compounds decrease the risk of some of these diseases is complex and sometimes unknown. All the different bioactive compounds may contribute to the overall health benefit since each vegetable family and each vegetable contain a unique combination of bioactive compounds. So the health benefit of vegetables should not be linked to only one bioactive compound or one type of vegetable, but rather with a balanced diet that includes more than one type of vegetable.

\section{Conflicts of Interest}

The author declares no conflicts of interest regarding the publication of this paper.

\section{References}

[1] Dias, J.S. and Ryder, E. (2011) World Vegetable Industry: Production, Breeding, Trends. Horticultural Reviews, 38, 299-356.

[2] Dias, J.S. (2012) Major Classes of Phytonutriceuticals in Vegetables and Health Benefits: A Review. Journal of Nutritional Therapeutics, 1, 31-62. https://doi.org/10.6000/1929-5634.2012.01.01.5

[3] Dias, J.S. (2012) Vegetable Breeding for Nutritional Quality and Health Benefits. In: Carbone, K., Ed., Cultivar. Chemical Properties, Antioxidant Activities and Health Benefits, Nova Science Publishers Inc., New York, 1-81. https://doi.org/10.4236/fns.2012.39159

[4] Prior, R.L. and Cao, G. (2000) Antioxidant Phytochemicals in Fruit and Vegetables, Diet and Health Implications. HortScience, 35, 588-592. https://doi.org/10.21273/HORTSCI.35.4.588

[5] Hyson, D. (2002) The Health Benefits of Fruit and Vegetables. A Scientific Overview for Health Professionals. Produce for Better Health Foundation, Wilmington DE.

[6] Golberg, G. (2003) Plants: Diet and Health. The Report of a British Nutrition Foundation Task Force. Blackwell Science, Oxford.

https://doi.org/10.1002/9780470774465

[7] International Fruit and Vegetable Alliance (IFAVA) (2006) Fruit, Vegetables and Health: A Scientific Overview. International Fruit and Vegetable Alliance, Ottawa, 
Canada.

[8] Malaterreb, A.S., Remizeb, F. and Pouchereta, P. (2018) Fruits and Vegetables, as a Source of Nutritional Compounds and Phytochemicals. Changes in Bioactive Compounds during Lactic Fermentation. Food Research International, 104, 86-99. https://doi.org/10.1016/j.foodres.2017.09.031

[9] Saura-Calixto, F. and Goñi, I. (2006) Antioxidant Capacity of the Spanish Mediterranean Diet. Food Chemistry, 94, 442-447. https://doi.org/10.1016/j.foodchem.2004.11.033

[10] Saura-Calixto, F., Serrano, J. and Goñi, I. (2007) Intake and Bioaccessibility of Total Polyphenols in a Whole Diet. Food Chemistry, 101, 492-501. https://doi.org/10.1016/j.foodchem.2006.02.006

[11] Kays, S.J. and Dias, J.S. (1995) Common Names of Commercially Cultivated Vegetables of the World in 15 Languages. Economic Botany, 49, 115-152. https://doi.org/10.1007/BF02862917

[12] Kays, S.J. (2011) Cultivated Vegetables of the World: A Multilingual Onomasticon. Wageningen Academic Publishers, Netherlands. https://doi.org/10.3920/978-90-8686-720-2

[13] Dias, J.S. (2014) Major Classes of Phytonutriceuticals in Vegetables and Health Benefits: A Review. In: Nath, P., Ed., The Basics of Human Civilization-Food, Agriculture and Humanity, Volume-II-Food, Prem Nath Agricultural Science Foundation (PNASF), Bangalore \& New India Publishing Agency (NIPA), New Delhi, India, 305-370.

[14] Nielsen, S.E., Young, J.F., Daneshvar, B., Lauriden, S.T., Knuthsen, P., Sandrstromand, B. and Dragsted, L.O. (1999) Effect of Parsley (Petroselinum crispum) Intake on Urinary Apigenin Excretion, Blood Antioxidant Enzymes and Biomarkers for Oxidative Stress in Human Subjects. British Journal of Nutrition, 81, 447-455. https://doi.org/10.1017/S000711459900080X

[15] Horbowicz, M., Kosson, R., Grzesiuk, A. and Bski, H.D. (2008) Anthocyanins of Fruits and Vegetables: Their Occurrence Analysis and Role in Human Nutrition. Vegetable Crops Research Bulletin, 68, 5-22. https://doi.org/10.2478/v10032-008-0001-8

[16] Lila, M.A. (2004) Anthocyanins and Human Health: An in Vitro Investigative Approach. Journal of Biomedicine and Biotechnology, 5, 306-313. https://doi.org/10.1155/S111072430440401X

[17] Ching, L.S. and Mohamed, S. (2001) Alpha-Tocopherol Content of 62 Edible Tropical Plants. Journal of Agricultural and Food Chemistry, 49, 3101-3105. https://doi.org/10.1021/jf000891u

[18] Crozier, A., Burns, J., Aziz, A.A, Stewart, A.J., Rabiasz, H.S., Jenkins, G.I., Edwards, C.A. and Lean, M.E.J. (2000) Antioxidant Flavonols from Fruits, Vegetables and Beverages: Measurements and Bioavailability. Biological Research, 33, 79-88. https://doi.org/10.4067/S0716-97602000000200007

[19] Prakash, D., Nath, P. and Pal, M. (1993) Composition, Variation of Nutritional Contents in Leaves, Seed Protein, Fat and Fatty Acid Profile of Chenopodium species. Journal of the Science of Food and Agriculture, 62, 203-205. https://doi.org/10.1002/jsfa.2740620214

[20] Sienera, R. (2006) Oxalate Contents of Species of the Polygonaceae, Amaranthaceae and Chenopodiaceae Families. Food Chemistry, 98, 220-224.

https://doi.org/10.1016/j.foodchem.2005.05.059 
[21] Dhillon, N.P.S., Monforte, A.J. and Pitrat, M. (2012) Melon Landraces of India: Contributions and Importance. Plant Breeding Reviews, 35, 85-150.

[22] Burger, Y., Yeselson, Y., Saar, U., Paris, H.S., Katzir, N., Tadmor, Y. and Schaffer, A.A. (2004) Screening of Melon (Cucumis melo) Germplasm for Consistently High Sucrose Content and for High Ascorbic Acid Content. In: Lebeda, A. and Paris, H.S., Eds., Progress in Cucurbit Genetics and Breeding Research, Palacky University, Olomouc, Czech Republic, 151-155.

[23] Crosby, K.M., Lester, G.E. and Leskovar, D.I. (2006) Genetic Variation for Beneficial Phytochemical Levels in Melons (Cucumis melo) In: Holmes, G.J., Ed., Cucurbitaceae 2006, Universal Press, Raleigh, NC, 70-76.

[24] Misra, S.K. (2012) Anti-Nutritive Bioactive Compounds Present in Unconventional Pulses and Legumes. Research Journal of Pharmaceutical, Biological and Chemical Sciences, 3, 586-597.

[25] Mallillin, A.C., Trinidad, T.P., Raterta, R., Dagbay, K. and Loyola, A.S. (2008) Dietary Fiber and Fermentability Characteristics of Root Crops and Legumes. British Journal of Nutrition, 100, 485-488. https://doi.org/10.1017/S000711450891151X

[26] Trinidad, T.P., Mallillin, A.C., Loyola, A.S., Sagum, R.S. and Encabo, R.R. (2010) The Potential Health Benefits of Legumes as a Good Source of Dietary Fiber. British Journal of Nutrition, 103, 569-574. https://doi.org/10.1017/S0007114509992157

[27] Dias, J.S. (2011) World Importance, Marketing and Trading of Vegetables. Acta Horticulturae, 921, 153-169. https://doi.org/10.17660/ActaHortic.2011.921.18

[28] Fahey, J.W., Zalcmann, A.T. and Talalay, P. (2001) The Chemical Diversity and Distribution of Glucosinolates and Isothiocyanates among Plants. Phytochemistry, 56, 5-51. https://doi.org/10.1016/S0031-9422(00)00316-2

[29] VanEtten, C.H., Dzenbichler, M.E., Williams, P. and Kwolek, W.F. (1976) Glucosinolates and Derived Products in Cruciferous Vegetables. Analysis in the Edible Part from Twenty-Two Varieties of Cabbage. Journal of Agricultural and Food Chemistry, 24, 452-455. https://doi.org/10.1021/jf60205a049

[30] Carlson, D.G., Daxenbichler, M.E., Van Etten, C.H., Tookey, H.L. and Williams, P.H. (1981) Glucosinolates in Crucifer Vegetables: Turnip and Rutabagas. Journal of Agricultural and Food Chemistry, 29, 1235-1239. https://doi.org/10.1021/jf00108a034

[31] Carlson, D.G., Daxenbichler, M.E., VanEtten, C.H., Hill, C.B. and Williams, P.H. (1985) Glucosinolates in Radish Cultivars. Journal of the American Society for Horticultural Science, 110, 634-638.

[32] Carlson, D.G., Daxenbichler, M.E., VanEtten, C.H., Hill, C.B. and Williams, P.H. (1987) Glucosinolates in Crucifer Vegetables: Broccoli, Brussels Sprouts, Cauliflower, Collards, Kale, Mustard Green, and Kohlrabi. Journal of the American Society for Horticultural Science, 112, 173-178.

[33] Carlson, D.G., Daxenbichler, M.E., VanEtten, C.H., Hill, C.B. and Williams, P.H. (1987) Glucosinolates in Turnip Tops and Roots: Cultivars Grown for Greens and/or Roots. Journal of the American Society for Horticultural Science, 112, 179-183.

[34] Kushad, M.K., Brown, A.F., Kurillicn, A.C., Juvik, J.A., Klein, B.P., Wallig, M.A. and Jeffery, E.H. (1999) Variation in Glucosinolates in Vegetable Crops of Brassica oleracea. Journal of Agricultural and Food Chemistry, 47, 1541-1548.

https://doi.org/10.1021/jf980985s

[35] Ciska, E., Martyniak-Przybyszewska, B. and Kozlowska, H. (2000) Content of Glu- 
cosinolates in Cruciferous Vegetables Grown at the Same Site for Two Years under Different Climatic Condition. Journal of Agricultural and Food Chemistry, 48, 2862-2867. https://doi.org/10.1021/jf981373a

[36] Vallejo, F., Tomas-Barberan, F.A., Banavent-Garcia, A.G. and Garcia-Viguera, C. (2003) Total and Individual Glucosinolate Contents in Inflorescences of Eight Broccoli Cultivars Grown under Various Climatic and Fertilization Conditions. Journal of the Science of Food and Agriculture, 83, 307-313.

https://doi.org/10.1002/jsfa.1320

[37] Nilsson, J., Olsson, K., Engqvist, G., Ekvall, J., Olsson, M., Nyman, M. and Åkesson, B. (2006) Variation in the Content of Glucosinolates, Hydroxycinnamic Acids, Carotenoids, Total Antioxidant Capacity and Low-Molecular-Weight Carbohydrates in Brassica Vegetables. Journal of the Science of Food and Agriculture, 86, 528-538. https://doi.org/10.1002/jsfa.2355

[38] Borkowski, J., Szajdek, A., Borkowska, E.J., Ciska, E. and Zielinski, H. (2008) Content of Selected Bioactive Components and Anti Oxidant Properties of Broccoli (Brassica oleracea L.). European Food Research and Technology, 226, 459-465. https://doi.org/10.1007/s00217-006-0557-9

[39] Cartea, M.E., Velasco, P., Obregón, S., Padilla, G. and de Haro, A. (2008) Seasonal Variation in Glucosinolate Content in Brassica oleracea Crops Grown in Northwestern Spain. Phytochemistry, 69, 403-410. https://doi.org/10.1016/j.phytochem.2007.08.014

[40] Hansen, M., Bengtsson, G.B., Borge, G.I., Berge, L. and Wold, A.B. (2010) Red Cabbage, a Vegetable Rich in Health-Related Glucosinolates. Acta Horticulturae, 867, 61-65. https://doi.org/10.17660/ActaHortic.2010.867.6

[41] Fahey, J.W., Zhang, Y.S. and Talalay, P. (1997) Broccoli Sprouts: An Exceptionally Rich Source of Inducers of Enzymes That Protects against Chemical Carcinogens. Proceedings of the National Academy of Sciences of the United States of America, 94, 10367-10372. https://doi.org/10.1073/pnas.94.19.10367

[42] Goodrich, R.M., Anderson, J.L. and Stoewsand, G. (1989) Glucosinolate Changes in Blanched Broccoli and Brussels Sprouts. Journal of Food Processing and Preservation, 13, 275-280. https://doi.org/10.1111/j.1745-4549.1989.tb00106.x

[43] Vallejo, F., Tomas-Barberan, F.A. and Garcia-Viguera, C. (2002) Potential Bioactive Compounds in Health Promotion from Broccoli Cultivars Grown in Spain. Journal of the Science of Food and Agriculture, 82, 1293-1297. https://doi.org/10.1002/jsfa.1183

[44] Kusznierewics, B., Bartoszek, A., Wolska, L., Drzewiwcki, J., Gorinstein, S. and Namiesnik, J. (2008) Partial Characterization of White Cabbages (Brassica oleracea var. capitata f. alba) from Different Regions by Glucosinolates, Bioactive Compounds, Total Antioxidant Activities and Proteins. LWT, 41, 1-9.

https://doi.org/10.1016/j.lwt.2007.02.007

[45] Cao, G., Sofic, E. and Prior, R.L. (1996) Antioxidant Capacity of Tea and Common Vegetables. Journal of Agricultural and Food Chemistry, 4, 3426-3431. https://doi.org/10.1021/jf9602535

[46] Scott, J., Releille, F. and Fletcher, J. (2000) Folic Acid and Folates: The Feasibility for Nutricional Enhancement in Plant Foods. Journal of the Science of Food and Agriculture, 80, 795-824.

https://doi.org/10.1002/(SICI)1097-0010(20000515)80:7<795::AID-JSFA599>3.0.CO $\underline{; 2-\mathrm{K}}$

[47] Konings, E.J.M., Roomans, H.H., Dorant, E., Goldbohm, R.A., Saris, W.H. and van 
den Brandt, P.A. (2001) Folate Intake of the Dutch Population According to Newly Established Liquid Chromatography Data for Foods. American Journal of Clinical, 73, 765-776. https://doi.org/10.1093/ajcn/73.4.765

[48] Banuelos, G. and Meek, D. (1989) Selenium Accumulation in Selected Vegetables. Journal of Plant Nutrition, 12, 1255-1272. https://doi.org/10.1080/01904168909364034

[49] Nencini, C., Cavallo, F., Capasso, A., Franchi, G.G., Giorgio, G. and Micheli, L. (2007) Evaluation of Antioxidative Properties of Allium Species Growing Wild in Italy. Phytotherapy Research, 21, 874-878. https://doi.org/10.1002/ptr.2168

[50] Kalra, N., Arora, A. and Shukla, Y. (2006) Involvement of Multiple Signaling Pathways in Diallyl Sulfide Mediated Apoptosis in Mouse Skin Tumors. Asian Pacific Journal of Cancer Prevention, 7, 556-562.

[51] Rose, P., Whiterman, M., Moore, P.K. and Zhu, Y.Z. (2005) Bioactive S-alk(en)yl Cysteine Sulfoxide Metabolites in the Genus Allium: The Chemistry of Potential Therapeutic Agents. Natural Product Reports, 22, 351-368. https://doi.org/10.1039/b417639c

[52] Rubec, R., Svobodovaand, M. and Velisek, J. (1999) Gas Chromatographic Determination of S-alk(en)yl-L-Cysteine Sulfoxides. Journal of Chromatography, 862, 85-94. https://doi.org/10.1016/S0021-9673(99)00902-4

[53] Thomas, D.J. and Parkin, K.L. (1994) Quantification of Alk(en)yl-L-Cysteine Sulfoxide and Related Amino Acids in Alliums by High-Performance Liquid Chromatography. Journal of Agricultural and Food Chemistry, 42, 1632-1638. https://doi.org/10.1021/jf00044a010

[54] Yoo, K.S. and Pike, L.M. (1998) Determination of Flavor Precursor Compound S-alk(en)yl- $L$-Cysteine Sulfoxides by HPLC Method and Their Distribution in Allium Species. Scientia Horticulturae, 75, 1-10. https://doi.org/10.1016/S0304-4238(98)00107-1

[55] Kubec, R., Svobodova, M. and Velisek, J. (1999) Gas-Chromatographic Determination of S-alk(eny)lylcysteine Sulfoxide. Journal of Chromatography, 862, 85-94. https://doi.org/10.1016/S0021-9673(99)00902-4

[56] Miean, K.H. and Mohamed, S. (2001) Flavonoid (Myricetin, Quercetin, Kaempferol, Luteolinand Apigenin) Content of Edible Tropical Plants. Journal of Agricultural and Food Chemistry, 49, 106-112. https://doi.org/10.1021/jf000892m

[57] Hertog, M.G., Hollman, P.C. and Katan, M.B. (1992) Content of Potentially Anticarcinogenic Flavonoids of 28 Vegetables and Fruits Commonly Consumed in the Netherlands. Journal of Agricultural and Food Chemistry, 40, 2379-2383. https://doi.org/10.1021/jf00024a011

[58] Bilyk, A. and Sapers, G.M. (1985) Distribution of Quercetin and Kaemperol in Lettuce, Kale, Chive, Garlic Chive Leek, Horseradish, Red Radish and Red Cabbage Tissue. Journal of Agricultural and Food Chemistry, 33, 226-228. https://doi.org/10.1021/jf00062a017

[59] Ip, C. and Lisk, D.J. (1994) Enrichment of Selenium in Allium Vegetables for Cancer Prevention. Carcinogenesis, 15, 1881-1885. https://doi.org/10.1093/carcin/15.9.1881

[60] Clinton, S. (1998) Lycopene: Chemistry, Biology and Implication for Human Health and Disease. Nutrition Reviews, 56, 35-51. https://doi.org/10.1111/j.1753-4887.1998.tb01691.x

[61] Scott, K.J. and Hart, D.J. (1995) Development and Evolution of an HPLC Method 
for the Analysis of Carotenoids Food and the Measurement of the Carotenoid Content Vegetables and Fruits Commonly Consumed in the UK. Food Chemistry, 54, 101-111. https://doi.org/10.1016/0308-8146(95)92669-B

[62] Tonucci, L.H., Holden, J.M., Beecher, G.R., Khachik, F., Davis, C.S. and Mulokozi, G. (1995) Carotenoid Content of Thermally Processed Tomato-Based Food Products. Journal of Agricultural and Food Chemistry, 43, 579-586. https://doi.org/10.1021/jf00051a005

[63] Gerster, H. (1997) The Potential Role of Lycopene for Human Health. Journal of the American College of Nutrition, 16, 109-126. https://doi.org/10.1080/07315724.1997.10718661

[64] Agarwal, S. and Rao, A.K. (2000) Tomato Lycopene and Its Role in Human Health and Chronic Diseases. Canadian Medical Association Journal, 163, 739-744.

[65] Rao, A.V. (2006) Tomatoes, Lycopene and Human Health Preventing Chronic Diseases. Caledonian Science Press, Stranraer, Scotland.

[66] Leonardi, C., Ambrosino, P., Esposito, F. and Fogliano, V. (2000) Antioxidant Activity and Caroteoid and Tomatine Contentes in Diferent Typologies of Fresh Consumption Tomatoes. Journal of Agricultural and Food Chemistry, 48, 4723-4727. https://doi.org/10.1021/jf000225t

[67] Arab, L. and Steck, S. (2000) Lycopene and Cardiovascular Disease. American Journal of Clinical Nutrition, 71, 1691S-1695S. https://doi.org/10.1093/ajcn/71.6.1691S

[68] Rao, A.V. and Rao, L.G. (2007) Carotenoids and Human Health. Pharmacological Research, 55, 207-216. https://doi.org/10.1016/j.phrs.2007.01.012

[69] Albushita, A.A., Daood, H.G. and Biacs, P.A. (2000) Change in Carotenoids and Antioxidant Vitamins in Tomato as a Function of Varietal and Technological Factors. Journal of Agricultural and Food Chemistry, 48, 2075-2081. https://doi.org/10.1021/jf990715p

[70] Albushita, A.A., Hebshi, E.A., Daood, H.G. and Biacs, P.A. (1997) Determination of Antioxidant Vitamins in Tomato. Food Chemistry, 60, 207-212. https://doi.org/10.1016/S0308-8146(96)00321-4

[71] Crozier, A., Lean, M.E., McDonaldand, M.S. and Black, C. (1997) Quantitative Analysis of the Flavonoid Content of Commercial Tomatoes, Onions, Lettuce and Celery. Journal of Agricultural and Food Chemistry, 45, 590-595. https://doi.org/10.1021/jf960339y

[72] Stewart, A.J. and Bozonnet, S. (2000) Mullen W. Jenkins GI, Lean ME, Crozier A. Occurrence of Flavonols in Tomatoes and Tomato-Based Products. Journal of Agricultural and Food Chemistry, 48, 2663-2669. https://doi.org/10.1021/jf000070p

[73] Craig, W. and Beck, L. (1999) Phytochemicals: Health Protective Effects. Canadian Journal of Dietetic Practice and Research, 60, 78-84.

[74] Dias, J.S. (2012) Nutritional Quality and Health Benefits of Vegetables: A Review. Food and Nutrition Research, 3, 1354-1347. https://doi.org/10.4236/fns.2012.310179

[75] Bosland, P.W. (1996) Capsicums: Innovative Uses of an Ancient Crop. In: Janick, J., Ed., Progress in New Crops, ASHS Press, Arlington, VA, 479-487.

[76] Howard, L.R., Talcott, S.T., Brenes, C.H. and Villalon, B. (2000) Changes in Phytochemical and Antioxidant Activity of Selected Pepper Cultivars (Capsicum species) as Influenced by Maturity. Journal of Agricultural and Food Chemistry, 48, 1713-1720. https://doi.org/10.1021/jf990916t

[77] Howard, L.R., Smith, R.T., Wagner, A.B., Villalon, B. and Burns, E.E. (1994) Provi- 
tamin A and Ascorbic Acid Content of Fresh Pepper Cultivars (Capsicum annum) and Processed Jalapenos. Journal of Food Science, 59, 362-365. https://doi.org/10.1111/j.1365-2621.1994.tb06967.x

[78] Lee, Y., Howard, R. and Villalon, B. (1995) Flavonoids and Antioxidant Activity of Fresh Pepper (Capsicum annum) Cultivars. Journal of Food Science, 60, 473-476. https://doi.org/10.1111/j.1365-2621.1995.tb09806.x

[79] Suzuki, T. and Iwai, K. (1984) The Alkaloids. In: Brossi, A., Ed., The Alkaloids Chemistry and Pharmacology, Vol. 13, Academic Press, San Diego, CA, 227-229.

[80] Thomas, B.V., Schreilber, A.A. and Weisskopf, C.P. (1998) Simple Method for Quantitation of Capsaicinoids in Pepper Using Capillary Gas Chromatography. Journal of Agricultural and Food Chemistry, 46, 2655-2663. https://doi.org/10.1021/jf970695w

[81] Frei, B. and Lawson, S. (2008) Vitamin C and Cancer Revisited. Proceedings of the National Academy of Sciences of the United States of America, 105, 11037-11038. https://doi.org/10.1073/pnas.0806433105

[82] Noda, Y., Kaneyuki, T., Igarashi, K., Moriand, A. and Pacer, L. (1998) Antioxidant Activity of Nasunin, an Anthocyanin in Eggplant. Research Communications in Chemical Pathology and Pharmacology, 102, 175-187.

[83] Kayamori, F. and Igarashi, K. (1994) Effect of Dietary Nasunin on the Serum Cholesterol Level in Rats. Bioscience, Biotechnology, and Biochemistry, 58, 570-571. https://doi.org/10.1271/bbb.58.570

[84] Noda, Y., Kneyuki, T. and Igarashi, K. (2000) Antioxidant Activity of Nasunin, an Anthocyanin in Eggplant Peels. Toxicology, 148, 119-123. https://doi.org/10.1016/S0300-483X(00)00202-X

[85] Matsuzoe, N., Yamaguchi, M., Kawanobu, S., Watanabe, Y., Higashi, H. and Sakata, Y. (1999) Effect of Dark Treatment of the Eggplant on Fruit Skin Color and Its Anthocyanin Components. Journal of the Japanese Society for Horticultural Science, 68, 138-145. https://doi.org/10.2503/jjshs.68.138

[86] Whitaker, B.D. and Stommel, J.R. (2003) Distribution of Hydroxycinnamic Acid Conjugates in Fruit of Commercial Eggplant (Solanum melongena L.) Cultivars. Journal of Agricultural and Food Chemistry, 51, 3448-3454. https://doi.org/10.1021/jf026250b

[87] Ben-Amos, A. and Fishler, R. (1998) Analysis of Carotenoids with Emphasis on 9-cis $\beta$-Carotene in Vegetables and Fruits Commonly Consumed in Israel. Food Chemistry, 62, 515-520. https://doi.org/10.1016/S0308-8146(97)00196-9

[88] Assimos, D.G. and Holmes, R.P. (2000) Role of Diet in the Therapy of Urolithiasis. Urologic Clinics of North America, 27, 255-268. https://doi.org/10.1016/S0094-0143(05)70255-X

[89] Britton, G. and Khachik, F. (2009) Carotenoids in Food. In: Britton, G., Pfander, H. and Liaaen-Jensens, S., Eds., Carotenoids, Birkhäuser, Basel, 45-66. https://doi.org/10.1007/978-3-7643-7501-0_3

[90] Fuhrman, J. (2013) The End of Diabetes: The Eat to Live Plan to Prevent and Reverse Diabetes. Harper Collins Publishers, New York.

[91] Pyo, Y.H., Lee, T.C., Logendrac, L. and Rosen, R.T. (2004) Antioxidant Activity and Phenolic Compounds of Swiss Chard (Beta vulgaris Subspecies cycla) Extracts. Food Chemistry, 85, 19-26. https://doi.org/10.1016/S0308-8146(03)00294-2

[92] Bolkent, S., Yanarda, R., Tabakolu-Oguz, A. and Ozsoy-Sacan, O. (2000) Effects of Chard (Beta vulgaris L. var. cicla) Extract on Pancreatic $\beta$ Cells in Streptozoto- 
cin-Diabetic Rats: A Morphological and Biochemical Study. Journal of Ethnopharmacology, 73, 251-259. https://doi.org/10.1016/S0378-8741(00)00328-7

[93] Mateljan, G. (2016) The World's Healthiest Foods. George Mateljan Foundation. Glendale, California.

[94] Kugler, F., Stintzing, F.C. and Carle, R. (2004) Identification of Betalains from Petioles of Differently Colored Swiss chard (Beta vulgaris L. ssp. cicla [L.] Alef. cv. Bright Lights) by High-Performance Liquid Chromatography-Electrospray Ion. Journal of Agricultural and Food Chemistry, 52, 2975-2981. https://doi.org/10.1021/jf035491w

[95] Dias, J.S. and Imai, S. (2017) Vegetables Consumption and Its Benefits on Diabetes. Journal of Nutritional Therapeutics, 6, 1-10. https://doi.org/10.6000/1929-5634.2017.06.01.1

[96] Poudyal, H., Panchal, S. and Brown, L. (2010) Comparison of Purple Carrot Juice and $\beta$-Carotene in a High-Carbohydrate, High-Fat Diet-Fed Rat Model of the Metabolic Syndrome. British Journal of Nutrition, 104, 1322-1332. https://doi.org/10.1017/S0007114510002308

[97] Dias, J.S. (2014) Nutritional and Health Benefits of Carrots and Their Seed Extracts. Food and Nutrition Research, 5, 2147-2156. https://doi.org/10.4236/fns.2014.522227

[98] Ferracane, R., Pellegrini, N., Visconti, A., Graziani, G., Chıavaro, E., Miglio, C. and Fogliano, V. (2008) Effects of Different Cooking Methods on Antioxidant Profile, Antioxidant Capacity, and Physical Characteristics of Artichoke. Journal of Agricultural and Food Chemistry, 56, 8601-8608. https://doi.org/10.1021/jf800408w

[99] World Health Organization (WHO) (2018) Increasing Fruit and Vegetable Consumption to Reduce the Risk of Non-Communicable Diseases. World Health Organization, E-Library of Evidence for Nutrition Actions (eLENA) World Health Organization, Geneva, Switzerland.

[100] Fergunson, L.R. (1999) Prospect of Cancer Prevention. Mutation Research, 428, 329-338. https://doi.org/10.1016/S1383-5742(99)00058-7

[101] American Institute of Cancer Research (AICR) (2007) Food, Nutrition, Physical Activity, and the Prevention of Cancer: A Global Perspective. AIRC/World Cancer Research Fund, Washington DC.

[102] Potter, J.D., Slattery, M.L. and Bostick, R.M. (1993) Colon Cancer: A Review of the Epidemiology. Epidemiologic Reviews, 15, 499-545.

https://doi.org/10.1093/oxfordjournals.epirev.a036132

[103] Van Duijnhoven, F.J., Bueno-de-Mesquita, H.B., Ferrari, P., Jenab, M., Boshuizen, H.C., Ros, M.M., Casagrande, C., Tjønneland, A., Olsen, A. and Overvad, K. (2009) Fruit, Vegetables and Colorectal Cancer Risk: The European Prospective Investigation into Cancer and Nutrition. American Journal of Clinical Nutrition, 89, 1441-1452. https://doi.org/10.3945/ajcn.2008.27120

[104] Trock, B., Lanza, E. and Greenwald, P. (1990) Dietary Fiber, Vegetables, and Colon cancer: Critical Review and Meta-Analysis of the Epidemiologic Evidence. Journal of the National Cancer Institute, 82, 650-661. https://doi.org/10.1093/jnci/82.8.650

[105] Neugut, A.I., Jacobson, J.S. and DeVivo, L. (1993) Epidemiology of Colorectal Adenomas: Macronutrients, Cholesterol and Fiber. Journal of the National Cancer Institute, 85, 884-891. https://doi.org/10.1093/jnci/85.11.884

[106] Steinmetz, K.A., Kushi, L.H., Bostick, R., Folisom, A.R. and Potter, J.D. (1994) Vegetable, Fruit and Colon Cancer in the Iowa Women's Health Study. American Journal of Epidemiology, 139, 1-15. 
https://doi.org/10.1093/oxfordjournals.aje.a116921

[107] Witte, J.S., Longnecker, M.P., Bird, S.L., Lee, E.R., Frakl, H.D. and Haile, R.W. (1996) Relation of Vegetable, Fruit and Grain Consumption to Colorectal Adenomatous Polyps. American Journal of Epidemiology, 144, 1015-1025.

https://doi.org/10.1093/oxfordjournals.aje.a008872

[108] Iscovich, J.M., L’Abbe, K.A., Castelleto, R., Calzona, A., Bernaedo, A., Chopita, N.A., Jmelnitzsky, A.C. and Kaldor, J. (1992) Colon Cancer in Argentina. Risk from Intake of Dietary Items. International Journal of Cancer, 51, 851-857. https://doi.org/10.1002/ijc.2910510603

[109] Zaridize, D., Filipchenco, V. and Kustov, V. (1993) Diet and Colorectal Cancer: Results of Two Case-Control Studies in Russia. European Journal of Cancer, 29, 113-115. https://doi.org/10.1016/0959-8049(93)90586-5

[110] Tanaka, S., Haruma, K., Yoshihara, M., Kajiyama, G., Kira, K., Amagase, H. and Chayama, K. (2006) Aged Garlic Extract Has Potential Suppressive Effect on Colorectal Adenomas in Humans. Journal of Nutrition, 136, 821S-826S. https://doi.org/10.1093/jn/136.3.821S

[111] Radhika, G., Sudha, V., Sathya, R.M., Ganesan, A. and Mohan, V. (2008) Association of Fruit and Vegetable Intake with Cardiovascular Risk Factors in Urban South Indians. British Journal of Nutrition, 99, 398-405. https://doi.org/10.1017/S0007114507803965

[112] Soh, Y., Shin, M., Lee, J., Jang, J., Kim, O.H., Kang, H. and Surh, Y. (2003) Oxidative DNA Damage and Glioma Cell Death Induced by Tetrahydropapaveroline. Mutation Research, 544, 129-142. https://doi.org/10.1016/j.mrrev.2003.06.023

[113] Tao, J., Li, Y., Li, S. and Li, H.B. (2018) Plant Foods for the Prevention and Management of Colon Cancer. Journal of Functional Foods, 42, 95-110. https://doi.org/10.1016/j.jff.2017.12.064

[114] Tewani, R., Sharma, J.K. and Rao, S.V. (2016) Spinach (Palak) Natural Laxative. International Journal of Applied Research and Technology, 1, 140-148.

[115] Verhoeven, D.T.H., Goldbohm, R.A., van Poppel, G., Verhagen, H. and van den Brandt, P.A. (1996) Epidemiological Studies on Brassica Vegetables and Cancer Risk. Cancer Epidemiology Biomarkers \& Prevention, 5, 733-751.

[116] Ambrosone, C.B., McCann, S.E., Freudenheim, J.L., Marshall, J.R., Zhang, Y. and Shields, P.G. (2004) Breast Cancer Risk in Premenopausal Women Is Inversely Associated with Consumption of Broccoli, a Source of Isothiocyanates, but Is Not Modified by GST Genotype. Journal of Nutrition, 134, 1134-1138. https://doi.org/10.1093/jn/134.5.1134

[117] Brennan, P., Hsu, C.C., Moullan, N., Szeszenia-Dabrowska, N., Lissowska, J., Zaridze, D., Rudnai, P., Fabianova, E., Mates, D. and Benckoet, V. (2005) Effect of Cruciferous Vegetables on Lung Cancer in Patients Stratified by Genetic Status: A Mendelian Randomisation Approach. The Lancet, 366, 1558-1560. https://doi.org/10.1016/S0140-6736(05)67628-3

[118] Kirsh, V.A., Peters, U., Mayne, S.T., Subar, A.F., Chatterjee, N., Johnson, C.C. and Hayes, R.B. (2007) Prospective Study of Fruit and Vegetable Intake and Risk of Prostate Cancer. Journal of the National Cancer Institute, 99, 1200-1209. https://doi.org/10.1093/jnci/djm065

[119] Traka, M. (2010) Broccoli Consumption Interferes with Prostate Cancer Progression: Mechanisms of Action. Acta Horticulturae, 867, 19-25.

https://doi.org/10.17660/ActaHortic.2010.867.1

[120] Seow, A., Yuan, J.M., Sun, C.L., Van Den Berg, D., Lee, H.P. and Yu, M.C. (2002) 
Dietary Isothiocyanates, Glutathione S-Transferase Polymorphisms and Colorectal Cancer Risk in the Singapore Chinese Health Study. Carcinogenesis, 23, 2055-2061. https://doi.org/10.1093/carcin/23.12.2055

[121] London, S.J., Yuan, J.M., Chung, F.L., Gao, Y.T., Coetzee, G.A., Ross, R.K. and Yu, M.C. (2000) Isothiocyanates, Glutathione S-Transferase M1 and T1 Polymorphisms, and Lung-Cancer Risk: A Propective Study of Men in Shanghai, China. The Lancet, 356, 724-729. https://doi.org/10.1016/S0140-6736(00)02631-3

[122] Fowke, J.H., Chung, F.L., Jin, F., Qi, D., Cai, Q., Conaway, C., Cheng, J.R., Shu, X.O., Gao, Y.T. and Zheng, W. (2003) Urinary Isothiocyanate Levels, brassica, and Human Breast Cancer. Cancer Research, 63, 3980-3986.

[123] Joseph, M.A., Moysich, K.B., Freudenheim, J.L., Shields, P.G., Bowman, E.D., Zhamg, Y., Marshall, J.R. and Ambrosone, C.B. (2004) Cruciferous Vegetables, Generic Polymorphism in Glutathione S-Transferases M1 and T1, and Protate Cancer Risk. Nutrition and Cancer, 50, 206-213. https://doi.org/10.1207/s15327914nc5002_11

[124] Juge, N., Mithen, R.F. and Traka, M. (2007) Molecular Basis for Chemoprevention by Sulforaphane: A Comprehensive Review. Cellular and Molecular Life Sciences, 64, 1105-1127. https://doi.org/10.1007/s00018-007-6484-5

[125] Zhang, Y. and Talalay, P. (1994) Anticarcinogenic Activities of Organic Isothiocyanate: Chemistry and Mechanisms. Cancer Research, 54, 1976s-1981s.

[126] Mithen, R., Faulkner, K., Magrath, R., Rose, P., Williamson, G. and Marquez, J. (2003) Development of Isothiocyanate Enriched Broccoli and Its Enhanced Ability to Induce Phase 2 Detoxification Enzymes in Mammalian Cells. Theoretical and Applied Genetics, 106, 727-734. https://doi.org/10.1007/s00122-002-1123-x

[127] Rosa EAS, Heaney RK, Fenewick GR, Portas CAM. (1997) Glucosinolates in Crop Plants. Horticultural Reviews, 19, 99-215.

[128] Abbaoui, B., Lucas, C.R. and Riedl, K.M. (2018) Cruciferous Vegetables, Isothiocyanates, and Bladder Cancer Prevention. Molecular Nutrition \& Food Research, 62, 1-50. https://doi.org/10.1002/mnfr.201800079

[129] Dorant, E., van Den Brandt, A., Goldbohm, R.A. and Sturnmans, F. (1996) Comsumption of Onions and a Reduced Risk of Stomach Carcinoma. Gastroenterology, 110, 12-20. https://doi.org/10.1053/gast.1996.v110.pm8536847

[130] You, W.C., Li, J.Y., Zhang, L., Jin, M.L., Chang, Y.S., Ma, J.L. and Pan, K.F. (2005) Etiology and Prevention of Gastric Cancer: A Population Study in High Risk Area of China. Chinese Journal of Digestive Disease, 6, 149-154. https://doi.org/10.1111/j.1443-9573.2005.00222.x

[131] Galeone, C., Pelucchi, C., Levi, F., Negri, E., Franceschi, S., Talamini, R., Giacosa, A. and La Vecchia, C. (2006) Onion and Garlic Use and Human Cancer. American Journal of Clinical Nutrition, 84, 1027-1032. https://doi.org/10.1093/ajcn/84.5.1027

[132] Grant, W.B. (2004) A Multicountry Ecologic Study of Risk and Risk Reduction Factors for Prostate Cancer Mortality. European Urology, 45, 271-279. https://doi.org/10.1016/j.eururo.2003.08.018

[133] Shon, M.Y., Choi, S.D., Kahng, G.G., Nam, S.H. and Sung, N.J. (2004) Antimutagenic, Antioxidant and Free Radical Scavenging Activity of Ethyl Acetate Extracts from White, Yellow and Red Onions. Food and Chemical Toxicology, 42, 659-666. https://doi.org/10.1016/j.fct.2003.12.002

[134] Yang, J., Meyers, K.J., vanderHeide, J. and Liu, R.H. (2004) Varietal Differences in Phenolic Content and Antioxidant and Antiproliferative Activities of Onions. Jour- 
nal of Agricultural and Food Chemistry, 52, 6787-6793.

https://doi.org/10.1021/jf0307144

[135] Kim, J.Y. and Kwon, O. (2009) Garlic Intake and Cancer Risk: An Analysis Using the Food and Drug Administration's Evidence-Based Review System for the Scientific Evaluation of Health Claims. American Journal of Clinical Nutrition, 89, 257-264. https://doi.org/10.3945/ajen.2008.26142

[136] Salem, S., Salahi, M., Mohseni, M., Ahmadi, H., Mehrsai, A., Jahani, Y. and Pourmand, G. (2011) Major Dietary Factors and Prostate Cancer Risk: A Prospective Multicenter Case-Control Study. Nutrition and Cancer, 63, 21-27.

[137] Iciek, M., Kwiecien, I. and Wlodek, L. (2009) Biological Properties of Garlic and Garlic-Derived Organosulfur Compounds. Environmental and Molecular Mutagenesis, 50, 247-265. https://doi.org/10.1002/em.20474

[138] Melino, S., Sabelli, R. and Paci, M. (2011) Allyl Sulfur Compounds and Cellular Detoxification System: Effects and Perspectives in Cancer Therapy. Amino Acids, 41, 103-112. https://doi.org/10.1007/s00726-010-0522-6

[139] You, W.C., Zhang, L., Gail, M.H., Ma, J.L., Chang, Y.S., Blot, W.J., Li, J.Y., Zhao, C.L., Liu, W.D., Li, H.Q., Hu, Y.R., Bravo, J.C., Correa, P., Xu, G.W. and Fraumeni, J.F. (1998) Helicobacter pylori Infection, Garlic Intake and Precancerous Lesions in a Chinese Population at Low Risk of Gastric Cancer. International Journal of Epidemiology, 27, 941-944. https://doi.org/10.1093/ije/27.6.941

[140] Tanaka, S., Haruma, K., Kunihiro, M., Nagata, S., Kitadai, Y., Manabe, N., Sumii, M., Yoshihara, M., Kajiyama, G. and Chayama, K. (2004) Effects of Aged Garlic Extract (AGE) on Colorectal Adenomas: A Double-Blinded Study. Hiroshima Journal of Medical Sciences, 53, 39-45.

[141] Fleischauer, A.T., Poole, C. and Arab, L. (2000) Garlic Consumption and Cancer Prevention: Meta-Analyses of Colorectal and Stomach Cancers. American Journal of Clinical Nutrition, 72, 1047-1052. https://doi.org/10.1093/ajcn/72.4.1047

[142] Hsing, A.W., Chokkalingam, A.P., Gao, Y.T., Madigan, M., Deng, J., Gridley, G. and Fraumeni, J.F. (2002) Allium Vegetables and Risk of Prostate Cancer: A Population-Based Study. Journal of the National Cancer Institute, 94, 1648-1651. https://doi.org/10.1093/jnci/94.21.1648

[143] Challier, B., Perarnau, J.M. and Viel, J.F. (1998) Garlic, Onion and Cereal Fibre as Protective Factors for Breast Cancer: A French Case-Control Study. European Journal of Epidemiology, 14, 737-747. https://doi.org/10.1023/A:1007512825851

[144] Galeone, C., Pelucchi, C., Dal Maso, L., Negri, E., Montella, M., Zucchetto, A., Talamini, R. and La Vecchia, C. (2009) Allium Vegetables Intake and Endometrial Cancer Risk. Public Health Nutrition, 12, 1576-1579. https://doi.org/10.1017/S1368980008003820

[145] Satia, J.A., Littman, A., Slatore, C.G., Galanko, J.A. and White, E. (2009) Associations of Herbal and Specialty Supplements with Lung and Colorectal Cancer Risk in the Vitamins and Lifestyle Study. Cancer Epidemiology Biomarkers \& Prevention, 18, 1419-1428. https://doi.org/10.1158/1055-9965.EPI-09-0038

[146] Wang, Y., Tian, W. and Ma, X. (2012) Inhibitory Effects of Onion (Allium cepa L.) Extract on Proliferation of Cancer Cells and Adipocytes via Inhibiting Fatty Acid Synthase. Asian Pacific Journal of Cancer Prevention, 13, 5573-5579. https://doi.org/10.7314/APJCP.2012.13.11.5573

[147] Burney, P.G., Comstock, G.W. and Morris, J.S. (1989) Serologic Precursors of Cancer: Serum Micronutrients and the Subsequent Risk of Pancreatic Cancer. American Journal of Clinical Nutrition, 49, 895-900. 
https://doi.org/10.1093/ajcn/49.5.895

[148] Van Eenwyk, J., Davis, F.G. and Bowen, P.E. (1991) Dietary and Serum Carotenoids and Cervical Intraepithelial Neoplasia. International Journal of Cancer, 48, 34-38. https://doi.org/10.1002/ijc.2910480107

[149] Franceschi, S., Bidoli, E., La Vecchia, C., Talamini, R., D’Avanzo, B. and Negri, E. (1994) Tomatoes and Risk of Digestive-Tract Cancers. International Journal of Cancer, 59, 181-184. https://doi.org/10.1002/ijc.2910590207

[150] Helzlsouer, K.J., Comstock, G.W. and Morris, J.S. (1989) Selenium, Lycopene, Alpha-Tocopherol, Beta-Carotene, Retinol, and Subsequent Bladder Cancer. Cancer Research, 49, 6144-6148.

[151] Gann, P.H., Ma, J. and Giovannucci, E. (1999) Lower Prostate Cancer Risk in Men with Elevated Plasma Lycopene Levels: Results of a Prospective Analysis. Cancer Research, 59, 1225-1230.

[152] Yuan, J.M., Ross, R.K., Gao, Y.T., Qu, Y.H., Chu, X.D. and Yu, M.C. (2004) Prediagnostic Levels of Serum Micronutrients in Relation to Risk of Gastric Cancer in Shanghai, China. Cancer Epidemiology Biomarkers \& Prevention, 13, 1772-1780.

[153] Wakai, K., Ando, M. and Ozasa, K. (2005) Updated Information on Risk Factors for Lung Cancer: Findings from the JACC Study. Journal of Epidemiology, 15, S134-S139. https://doi.org/10.2188/jea.15.S134

[154] Giovannucci, E. (1999) Tomatoes, Tomato Based Products, Lycopene and Cancer: Review of the Epidemiological Literature. Journal of the National Cancer Institute, 91, 917-331. https://doi.org/10.1093/jnci/91.4.317

[155] Jang, J. and Surh, Y. (2003) Potentiation of Cellular Antioxidant Capacity by Bcl-2: Implications for Its Antiapoptotic Function. Biochemical Pharmacology, 66, 1371-1379. https://doi.org/10.1016/S0006-2952(03)00487-8

[156] Hadley, C.W., Miller, E.C., Schwartz, S.J. and Clinton, S.K. (2002) Tomatoes, Lycopene, and Prostate Cancer: Progress and Promise. Experimental Biology and Medicine, 227, 869-880. https://doi.org/10.1177/153537020222701006

[157] Giovannucci, E., Ashcerio, A. and Rimm, E.B. (1995) Intake of Carotenoids and Retinol in Relation to Risk of Prostate Cancer. Journal of the National Cancer Institute, 87, 1767-1776. https://doi.org/10.1093/jnci/87.23.1767

[158] Clark, R. and Lee, S.H. (2016) Anticancer Properties of Capsaicin against Human Cancer. Anticancer Research, 36, 837-844.

[159] Nagase, H., Sasaki, K., Kito, H., Haga, A. and Sato, T. (1998) Inhibitory Effect of Delphinidin from Solanum Melongena on Human Fibrosarcoma HT-1080 Invasiveness in Vitro. Planta Medica, 64, 216-219. https://doi.org/10.1055/s-2006-957412

[160] Goldwyn, S., Lazinskyand, A., Wei, H. (2000) Promotion of Health by Soy Isoflavones: Efficacy, Benefitand Safety Concerns. Drug Metabolism and Drug Interactions, 17, 261-289. https://doi.org/10.1515/DMDI.2000.17.1-4.261

[161] Sarkar, F.H. and Li, Y. (2006) Isoflavones, Soybean Phytoestrogens, and Cancer. In: Awad, A.B. and Bradford, P.G., Eds., Nutrition and Cancer Prevention, CRC Press, Boca Raton, 295-312.

[162] Ziegler, R.G., Hooverand, R.N. and Hildeshein, R.N. (1993) Migration Patterns and Breast Cancer Risk in Asian-America Women. Journal of the National Cancer Institute, 85, 1819-1827. https://doi.org/10.1093/jnci/85.22.1819

[163] Lamartiniere, C. (2000) Protection against Breast Cancer with Genistein: A Component of Soy. American Journal of Clinical Nutrition, 71, 1705S-1707S. 
https://doi.org/10.1093/ajcn/71.6.1705S

[164] Steiner, C., Arnould, S., Scalbert, A. and Manach, C. (2008) Isoflavones and the Prevention of Breast and Prostate Cancer: New Perspectives Opened by Nutrigenomics. British Journal of Nutrition, 99, 78-108. https://doi.org/10.1017/S0007114508965788

[165] Messina, M.J. and Wood, C.E. (2008) Soy Isoflavones, Estrogen Therapy, and Breast Cancer Risk: Analysis and Commentary. Nutrition Journal, 7, 17. https://doi.org/10.1186/1475-2891-7-17

[166] Dong, J.Y. and Qin, L.Q. (2011) Soy Isoflavones Consumption and Risk of Breast Cancer Incidence or Recurrence: A Meta-Analysis of Prospective Studies. Breast Cancer Research and Treatment, 125, 315-323. https://doi.org/10.1007/s10549-010-1270-8

[167] Jiang, H.Y., Lv, F.J. and Tai, J.Q. (2000) Bioactive Components of Soybean and Their Function. Soybean Science, 19, 160-164.

[168] Sarkar, F.H. and Li, Y. (2003) Soy Isoflavones and Cancer Prevention. Cancer Investigation, 21, 744-757. https://doi.org/10.1081/CNV-120023773

[169] Zaini, R., Clench, M.R. and Maitre, C.L. (2011) Bioactive Chemicals from Carrot (Daucus carota) Juice Extracts for the Treatment of Leukemia. Journal of Medicinal Food, 14, 1303-1312. https://doi.org/10.1089/jmf.2010.0284

[170] Larsen, M.K., Christensen, L.P., Vach, W., Hoitinga, R.J. and Brant, K. (2005) Inhibitory Effects of Feeding with Carrots or Falcarinol on Development of Azoxymethame-Induced Preneoplastic Lesions in the Rat Colon. Journal of Agricultural and Food Chemistry, 53, 1823-1827. https://doi.org/10.1021/jf048519s

[171] Purup, S., Larsen, E. and Christesen, L.P. (2009) Differential Effects of Falcarinol and Related Aliphatic C17-Polyacetylenes on Intestinal Cell Proliferation. Journal of Agricultural and Food Chemistry, 57, 8290-8296. https://doi.org/10.1021/jf901503a

[172] Pisani, P., Berrino, F., Macaluso, M., Pastorino, U., Crosignani, P. and Baldasseroni, A. (1986) Carrots, Green Vegetables and Lung Cancer: A Case-Control Study. International Journal of Epidemiology, 15, 463-468. https://doi.org/10.1093/ije/15.4.463

[173] Mullie, P. and Clarys, P. (2011) Association between Cardiovascular Disease Risk Factor Knowledge and Lifestyle. Food and Nutrition Research, 2, 1048-1053. https://doi.org/10.4236/fns.2011.210140

[174] Roth, G.A., Forouzanfar, M.H., Moran, A.E., Barber, R., Nguyen, G., Feigin, V.L., Murray, C.J. (2015) Demographic and Epidemiologic Drivers of Global Cardiovascular Mortality. New England Journal of Medicine, 372, 1333-1341. https://doi.org/10.1056/NEJMoa1406656

[175] Liu, S., Lee I.M., Ajani, U., Cole, S.R., Buring, J.E. and Manson, J.E. (2001) Intake of Vegetables Rich in Carotenoids and Risk of Coronary Heart Disease in Men: The Physicians' Health Study. International Journal of Epidemiologyiol, 30, 130-135. https://doi.org/10.1093/ije/30.1.130

[176] American Heart Association (AHA) (2017) Heart and Stroke Statistical Update. American Heart Association, Dallas, TX.

[177] Yeh, Y.Y. and Liu, L. (2001) Cholesterol-Lowering Effect of Garlic Extracts and Organosulfur Compounds: Human and Animal Studies. Journal of Nutrition, 131, 989-993. https://doi.org/10.1093/jn/131.3.989S

[178] Moriguchi, T., Takasugi, N. and Itakura, Y. (2001) The Effects of Aged Garlic Extract on Lipid Peroxidation and the Deformability of Erythrocytes. Journal of Nutri- 
tion, 131, 1016-1019. https://doi.org/10.1093/jn/131.3.1016S

[179] Chang, H.S., Yamato, O., Yamasaki, M. and Maede, Y. (2005) Modulatory Influence of Sodium 2-Propenylthiosulfate from Garlic on Cyclooxygenase Activity in Canine Platelets: Possible Mechanism for the Anti-Aggregatory Effect. Prostaglandins, Leukotrienes and Essential Fatty Acids, 72, 351-355. https://doi.org/10.1016/j.plefa.2005.01.003

[180] Osmont, K.S., Arnt, C.R. and Goldman, I.L. (2003) Temporal Aspects of Onion-Induced Antiplatelet Activity. Plant Foods for Human Nutrition, 58, 27-40. https://doi.org/10.1023/A:1024062330700

[181] Hubbard, G.P., Wolffram, S., Lovegrove, J.A. and Gibbins, J.M. (2006) Ingestion of Quercetin Inhibits Platelet Aggregation and Essential Components of the Collagen-Stimulated Platelet Activation Pathway in Man: A Pilot Study. Journal of Thrombosis and Haemostasis, 2, 2138-2145.

https://doi.org/10.1111/j.1538-7836.2004.01067.x

[182] Briggs, W.H., Folt, J.D., Osman, H.E. and Goldman, I.L. (2001) Administration of Raw Onion Inhibits Platelet-Mediated Thrombosis in Dogs. Journal of Nutrition, 131, 2619-2622. https://doi.org/10.1093/jn/131.10.2619

[183] Ried, K., Frank, O.R. and Stocks, N.P. (2013) Aged Garlic Extract Reduces Blood Pressure in Hypertensives: A Dose-Response Trial. European Journal of Clinical Nutrition, 67, 64-70. https://doi.org/10.1038/ejcn.2012.178

[184] Freudenheim, J.L., Graham, S., Marshall, J.R., Haughey, B.P. and Wilkinson, G. (1990) A Case-Control Study of Diet and Rectal Cancer in Western New York. American Journal of Epidemiology, 131, 612-624.

https://doi.org/10.1093/oxfordjournals.aje.a115545

[185] Knekt, P., Jarvinen, R., Reunanen, A. and Maatela, J. (1996) Flavonoid Intake and Coronary Mortality in Finland: A Cohort Study. BMJ, 312, 478-481. https://doi.org/10.1136/bmj.312.7029.478

[186] Rastogi, T., Reddy, K.S., Vaz, M., Spiegelman, D., Prabhakaran, D., Willett, W.C. and Ascherio, A. (2004) Diet and Risk of Ischemic Heart Disease in India. American Journal of Clinical Nutrition, 79, 582-592. https://doi.org/10.1093/ajcn/79.4.582

[187] Saluk, J., Bijak, M., Kołodziejczyk-Czepas, J., Posmyk, M., Janas, K. and Wachowicz, B. (2012) Anthocyanins from Red Cabbage Extract-Evidence of Protective Effects on Blood Platelets. Open Life Sciences, 7, 655-663. https://doi.org/10.2478/s11535-012-0057-9

[188] Manchali, S., Murthy, K.N.C. and Patil, B.S. (2012) Crucial Facts about Health Benefits of Popular Cruciferous Vegetables. Journal of Functional Foods, 4, 94-106. https://doi.org/10.1016/j.jff.2011.08.004

[189] Jeffery, E.H. and Araya, M. (2009) Physiological Effects of Broccoli Consumption. Phytochemistry Reviews, 8, 283-298. https://doi.org/10.1007/s11101-008-9106-4

[190] Murashima, M., Watanabe, S., Zhuo, X.G., Uehara, M. and Kurashige, A. (2004) Phase 1 Study of Multiple Biomarkers for Metabolism and Oxidative Stress after One-Week Intake of Broccoli Sprouts. BioFactors, 22, 271-275. https://doi.org/10.1002/biof.5520220154

[191] Jorge, P.A., Neyra, L.C. and Osaki, R.M. (1998) Effect of Eggplant on Plasma Lipid Levels, Lipidic Peroxidation and Reversion of Endothelial Dysfunction in Experimental Hypercholesterolemia. Arquivos Brasileiros de Cardiologia, 70, 87-91. https://doi.org/10.1590/S0066-782X1998000200004

[192] Guimarães, P.R., Galvão, A.M., Batista, C.M., Azevedo, G.S., Oliveira, R.D., 
Lamounier, R., Freire, N., Barros, A., Sakurai, E., Oliveira, J., Vieira, E. and Alvarez-Leite, J. (2000) Eggplant (Solanum melongena) Infusion has a Modest and Transitory Effect on Hypercholesterolemic Subjects. Brazilian Journal of Medical and Biological Research, 33, 1027-1036. https://doi.org/10.1590/S0100-879X2000000900006

[193] Kwon, Y.I., Apostolidis, E. and Shetty, K. (2008) In Vitro Studies of Eggplant (Solanum melongena) Phenolics as Inhibitors of Key Enzymes Relevant for Type 2 Diabetes and Hypertension. Bioresource Technology, 99, 2981-2988.

https://doi.org/10.1016/j.biortech.2007.06.035

[194] Anderson, J.W., Deakins, D.A., Floore, T.L., Smith, B.M. and Whitis, S.E. (1990) Dietary Fiber and Coronary Heart Disease. Critical Reviews in Food Science and Nutrition, 29, 95-147. https://doi.org/10.1080/10408399009527518

[195] Menotti, A., Kromhout, D., Blackburn, H., Fidanza, F., Buzina, R. and Nissinen, A. (1999) Food Intake Patterns and 25-Year Mortality from Coronary Heart Disease: Cross-Cultural Correlations in the Seven Countries Study. European Journal of Epidemiology, 15, 507-515. https://doi.org/10.1023/A:1007529206050

[196] Nöthlings, U., Schulze, M.B., Weikert, C., Boeing, H., Van der Schouw, Y.T., Bamia, C. and Peeters, P.H. (2008) Intake of Vegetables, Legumes, and Fruit, and Risk for All-Cause, Cardiovascular, and Cancer Mortality in a European Diabetic Population. Journal of Nutrition, 138, 775-781. https://doi.org/10.1093/jn/138.4.775

[197] Lattimer, J.M. and Haub, M.D. (2010) Effects of Dietary Fiber and Its Components on Metabolic Health. Nutrients, 2, 1266-1289. https://doi.org/10.3390/nu2121266

[198] Nicolle, C., Cardinault, N., Aprikian, O., Busserolles, J., Grolier, P., Rock, E., Demigné, C., Mazur, A., Scalbert, A., Amouroux, P. and Rémésy, C. (2003) Effect of Carrot Intake on Cholesterol Metabolism and on Antioxidant Status in Cholesterol-Fed Rat. European Journal of Nutrition, 42, 254-261. https://doi.org/10.1007/s00394-003-0419-1

[199] Gramenzi, A., Gentile, A., Fasoli, M., Negri, E., Parazzini, F. and La Vecchia, C. (1990) Association between Certain Foods and Risk of Acute Myocardial Infarction in Women. BMJ, 300, 771-773. https://doi.org/10.1136/bmj.300.6727.771

[200] Gilani, A.H., Shaheeri, F., Saeed, S.A., Bibi, S., Irfamillah-Sadiq, M. and Faiz, S. (2000) Hypotensive Action of Coumarin Glycoside from Daucus Carot. Phytomedicine, 7, 423-426. https://doi.org/10.1016/S0944-7113(00)80064-1

[201] Carter, P., Gray, L.J., Troughton, J., Khunti, K. and Davies, M.J. (2010) Fruit and Vegetable Intake and Incidence of Type 2 Diabetes Mellitus: Systematic Review and Meta-Analysis. BMJ, 341, c4229. https://doi.org/10.1136/bmj.c4229

[202] Bazzano, L.A., Li, T.Y., Joshipura, K.J. and Hu, F.B. (2008) Intake of Fruit, Vegetables and Fruit Juices and Risk of Diabetes in Women. Diabetes Care, 31, 1311-1317. https://doi.org/10.2337/dc08-0080

[203] Khan, B.A., Abraham, A. and Leelamma, S. (1995) Hypoglycemic Action of Murraya koeingii (Curry Leaf) and Brassica juncea (Mustard): Mechanism of Action. Indian Journal of Biochemistry \& Biophysics, 32, 106-108.

[204] Tundis, R., Loizzo, M.R. and Menichini, F. (2010) Natural Products as Alpha-Amylase and Alpha-Glucosidase Inhibitors and Their Hypoglycaemic Potential in the Treatment of Diabetes: An Update. Mini-Reviews in Medicinal Chemistry, 10, 315-331. https://doi.org/10.2174/138955710791331007

[205] Yoshikawa, M., Murakami, T., Kadoya, M., Yamahara, J. and Matsuda, H. (1996) Medicinal Foodstuff. III. Sugar Beet. Hypoglicemic Oleanolic Acid Oligoglycosides, Betavulgarosides I, II, III, and IV, from the Root of Beta vulgaris L. (Chenopodia- 
ceae). Chemical and Pharmaceutical Bulletin, 44, 1212-1217.

https://doi.org/10.1248/cpb.44.1212

[206] American Diabetes Association (ADA) (2016) Standards of Care. Diabetes Care, 39, S1-S119.

[207] Gu, J.F., Zheng, Z.Y., Yuan, J.R., Zhao, B.J., Wang, C.F., Zhang, L., Xu, Q.Y., Yin, Q.W., Feng, L. and Jia, X.B. (2015) Comparison on Hypoglycemic and Antioxidant Activities of the Fresh and Dried Portulaca oleracea L. in Insulin-Resistant HepG2 Cells and Streptozotocin-Induced C57BL/6J Diabetic Mice. Journal of Ethnopharmacologyogy, 161, 214-223. https://doi.org/10.1016/j.jep.2014.12.002

[208] Wainstein, J., Landau, Z., Dayan, Y.B., Jakubowicz, D., Grothe, T., Perrinjaquet-Moccetti, T. and Boaz, M. (2016) Purslane Extract and Glucose Homeostasis in Adults with Type 2 Diabetes: A Double-Blind, Placebo-Controlled Clinical Trial of Efficacy and Safety. Journal of Medicinal Food, 19, 133-140.

https://doi.org/10.1089/jmf.2015.0090

[209] Swamy, K.R.M., Nath, P. and Ahuja, K.G. (2013) Vegetables for Human Nutrition and Health. In: Nath, P., Ed., The Basics of Human Civilization-Food, Agriculture and Humanity, Volume-II-Food, Prem Nath Agricultural Science Foundation (PNASF), Bangalore \& New India Publishing Agency (NIPA), New Delhi, India, 145-198.

[210] El-Demerdash, F.M., Yousef, M.I. and El-Naga, N.A. (2005) Biochemical Study on the Hypoglycemic Effects of Onion and Garlic in Alloxan-Induced Diabetic Rats. Food and Chemical Toxicology, 43, 57-63. https://doi.org/10.1016/j.fct.2004.08.012

[211] Ogunmodede, O.S., Saalu, L.C., Ogunlade, B., Akunna, G.G. and Oyewopo, A.O. (2012) An Evaluation of the Hypoglycemic, Antioxidant and Hepatoprotective Potentials of Onion (Allium cepa L.) on Alloxan-Induced Diabetic Rabbits. International Journal of Pharmacology, 8, 21-29.

https://doi.org/10.3923/ijp.2012.21.29

[212] Yoshinari, O., Shiojima, Y. and Igarashi, K. (2012) Anti-Obesity Effects of Onion Extract in Zucker Diabetic Fatty Rats. Nutrients, 4, 1518-1526. https://doi.org/10.3390/nu4101518

[213] Wang, H., Kruszewki, A. and Brautigan, D.L. (2005) Cellular Chromium Activation of Insulin Receptor Kinase. Biochemistry, 44, 8167-8175. https://doi.org/10.1021/bi0473152

[214] Chau, C.F., Chen, C.H. and Lee, M.H. (2004) Comparison of the Characteristics, Functional Properties, and in Vitro Hypoglycemic Effects of Various Carrot Insoluble Fiber-Rich Fractions. Lebensmittel- Wissenshaff und Technologie, 37, 155-160. https://doi.org/10.1016/j.lwt.2003.08.001

[215] Coyne, T., Ibiebele, T.I. and Baade, P.D. (2005) Diabetes Mellitus and Serum Carotenoids: Findings of a Population-Based Study in Queensland, Australia. American Journal of Clinical Nutrition, 82, 685-693. https://doi.org/10.1093/ajcn/82.3.685

[216] Chen, Q., Chan, L.L.Y. and Li, E. (2003) Bitter Melon (Momordica charantia) Reduces Adiposity, Lowers Serum Insulin and Normalizes Glucose Tolerance in Rats Fed a High Fat Diet. Journal of Nutrition, 133, 1088-1093. https://doi.org/10.1093/jn/133.4.1088

[217] Patil, B., Jayaprakasha, G.K. and Vikram, A. (2012) Indigenous Crops of Asia and Southeast Asia: Exploring Health-Promoting Properties. HortScience, 47, 821-827. https://doi.org/10.21273/HORTSCI.47.7.821

[218] Chao, P.M. (2015) One More Support for Recruiting Bitter Melon in Therapeutic 
Diet for Diabetes and Its Comorbidity Management-Bitter Melon Ameliorates Hepatic Steatosis Related with Hyperglycemia. BIT s 4 th Annual World Congress of Diabetes, Kaohsiung, 13-16 November 2014, 236.

[219] Ahmad, N., Hassan, M., Halder, H. and Bennoor, K. (1999) Effect of Momordica charantia (Karolla) Extracts on Fasting and Postprandial Serum Glucose Levels in NIDDM Patients. Bangladesh Medical Research Council Bulletin, 25, 11.

[220] Yeh, G., Eisenberg, D., Kaptchuk, T. and Phillips, R. (2003) Systematic Review of Herbs and Dietary Supplements for Glycemic Control in Diabetes. Diabetes Care, 26, 1277. https://doi.org/10.2337/diacare.26.4.1277

[221] Chen, J., Tian, R., Qiu, M., Lu, L., Zheng, Y. and Zhang, Z. (2008) Trinorcucurbitane and Cucurbitane Triterpenoids from the Roots of Momordica charantia. Phytochemistry, 69, 1043-1048.

https://doi.org/10.1016/j.phytochem.2007.10.020

[222] Saxena, A. and Vikram, N. (2004) Role of Selected Indian Plants in Management of Type 2 Diabetes: A Review. Journal of Alternative and Complementary Medicine, 10, 369-378. https://doi.org/10.1089/107555304323062365

[223] Singh, L.W. (2011) Traditional Medicinal Plants of Manipur as Anti-Diabetics. Journal of Medicinal Plant Research, 5, 677-687.

[224] Villegas, R., Gao, Y.T., Yang, G., Li, H.L., Elasy, T.A., Zheng, W. and Shu, X.O. (2008) Legume and Soy Food Intake and the Incidence of Type 2 Diabetes in the Shanghai Women's Health Study. American Journal of Clinical Nutrition, 87, 162-167. 